\title{
The effect of the textbook written according to the principles of prose learning on the student achievement
}

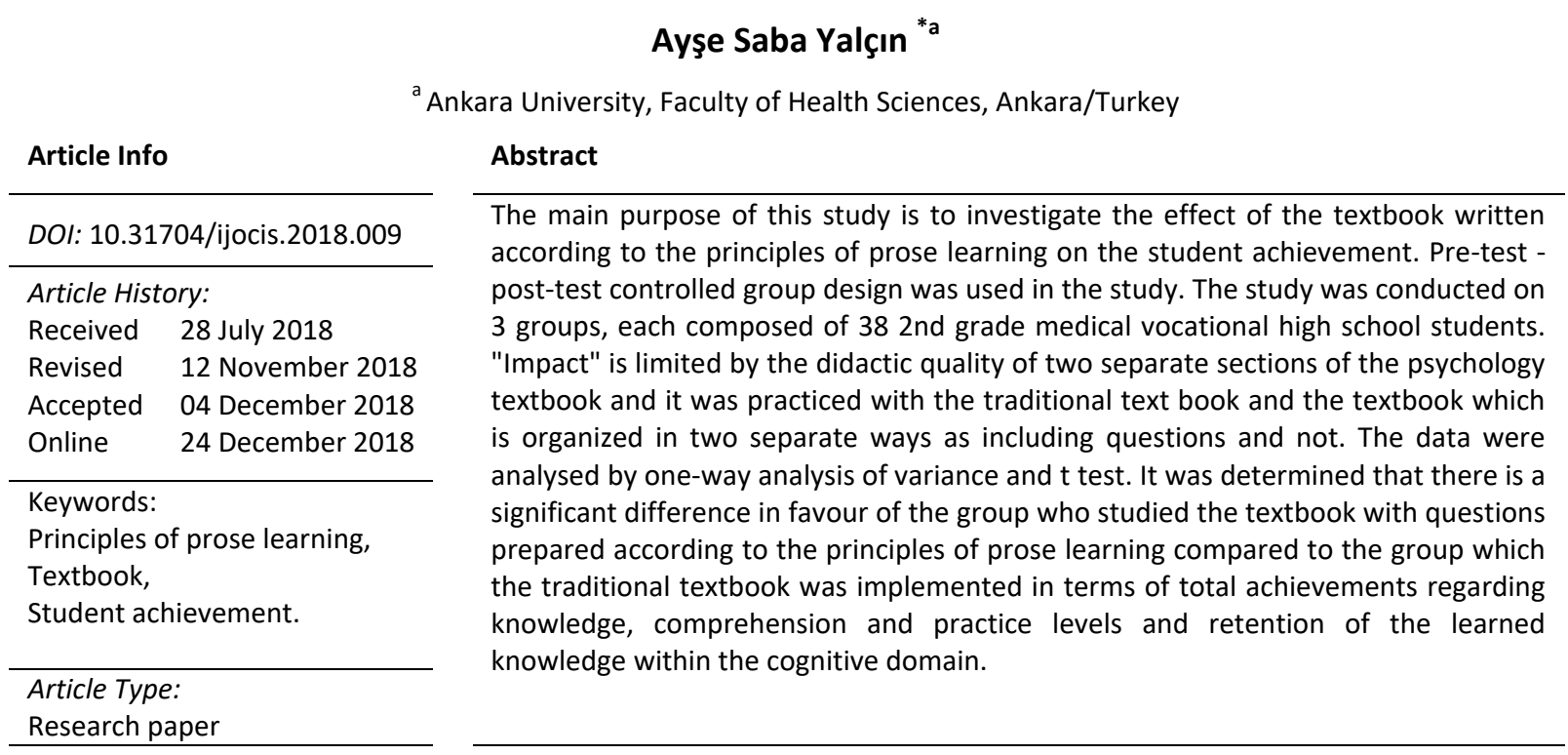

\section{Metinden öğrenme ilkelerine göre hazırlanan ders kitabının} öğrenci erişisine etkisi

Makale Bilgisi

DOI: 10.31704/ijocis.2018.009

Makale Geçmişi:

Geliş 14 Temmuz 2018

Düzeltme 12 Kasım 2018

Kabul 04 Aralık 2018

Çevrimiçi 24 Aralık 2018

\section{Anahtar Kelimeler:}

Metinden öğrenme ilkeleri, Ders kitabı,

Öğrenci erişişi.

Makale Türü:

Özgün makale
Öz

Bu çalışmanın temel amacı, metinden öğrenme ilkelerine göre hazırlanan ders kitabının, öğrenci erişisi üzerindeki etkisini araştırmaktır. Araştırmada, ön test - son test kontrollü grup deseninden yararlanılmıştır. Sağlık Meslek Lisesi, 2. sınıf öğrencilerinden her biri 38 öğrenciden oluşan, 3 grup üzerinde çalışma yapılmıştır. Çalışmada, "Etki", psikoloji ders kitabının iki ayrı bölümünün öğreticiliği ile sınırlandırılmış, geleneksel kitap ile sorusuz ve sorulu iki ayrı şekilde düzenlenen ders kitabı ile uygulama yapılmıştır. Veriler, tek yönlü varyans analizi ve t testi yapılarak çözümlenmiştir. Metinden öğrenme ilkelerine göre hazırlanan sorusuz ve sorularla desteklenen ders kitabı ile geleneksel ders kitabını okuyan grupların toplam erişileri ile bilişsel alanın bilgi, kavrama, uygulama düzeyleri ve öğrenilen bilgileri hatırlama bakımından toplam erişileri arasında sorulu grup lehine anlamlı bir fark olduğu ve geleneksel ders kitabının uygulandığı gruba göre daha başarılı oldukları sonucu bulunmuştur. 


\section{Introduction}

Education is the study of gaining desired behaviors containing practices having their objectives set. Bolat (2014) stated that curricula are the most important element in organizing learning experiences. Textbook being another major factor is the study material included in the written and printed materials group which constitutes the basis of the student's learning experiences. Textbook plays a vital role, especially in prose learning.

In the literature we come across with different opinions about the role of text in learning. According to one view, text is a dynamic force enabling the development and change of students. According to another study, text is rather memorized. This memorization directs student-teacher interactions. Students also try to comprehend the text as it is without adding comments. In text design of the textbooks, students' characteristic such as their level, interests, expectations need to be defined. In the 20th century, textbooks were considered to be important in education; however, nowadays there are different opinions about this issue. There are also studies arguing that textbooks have begun to lose importance as teaching materials for the preparatory phase of learning lives and teaching materials designed in line with the new technologies and computerized teaching would be more important. The use of new technologies in education facilitates educational activities as a result of the interaction of more sensory organs when compared to traditional methods (Balaman, 2016; Balaman \& Tüysüz, 2011; Yanpar, 2006).

Soong and Yager (1993) emphasized that most of the students consider textbooks as the source of all the information and the students' parents react to this situation when the textbooks are not used in the same sense. Ünal and Pideci (2000) stated that the textbooks provide the students with the opportunity such as being prepared for the course, reaching abstract information in a wide range of information, to be able to jointly use them in homework and group works. Demirel (1999) emphasized the importance of textbooks for students to achieve the qualifications required by the curriculum and books are most widely used among the visual aids during educational period. After determining the objectives of a course and defining indicative behaviors the selection of the tools and equipment to be used to acquire these behaviors are of great importance. Therefore, the textbook having an important place among them has to be qualified. Aslantaş and Demirci (2016) emphasized that textbooks are important to further develop students' creativity and for that reason textbooks should have some sort of qualifications.

Textbooks should have some characteristics in order for them to serve the objectives in teaching-learning environment. Ünsal and Güneş (2003) state that overall achievement of a textbook can be understood by investigating some basic criteria such as physical properties, content-presentation alignment, visual presentation language and narration. Arslan and Özpınar (2009) focused on some components like compliance with curriculum, preparatory studies, assessment and evaluation, scientific content, language and narration, visual order, design principles and elements to investigate textbooks.

Yalın (1996) also underlined that in overall assessment of textbooks in our country, the primary issue is mostly the regard paid to the content of books. In terms of students' learning motivation and achievement, in textbooks the use of visual order leveraging the learning level of the information contained in the text is so important. Visual aids, enables students to recover relevant concept from abstractness and make a sense for processes. Dursun and Eşgi (2008) emphasized that visual aids in textbooks have some major functions such as informing students, supporting information, directing attention by arousing interest, summarizing the subjects, illustrate relationships between cases and facts, and making complex topics that are hard to envisage easier to understand.

Yeşilyurt and Gül (2008); Yıldıran (2007); Altunoğlu and Atav (2005) defined in their studies that the evaluation of textbooks in terms of visual aid was neglected and textbooks are inadequate in this aspect. Özay and Hasenekoğlu (2007); Yalın (1996); Güneş (2002); Kabapınar (2003) pointed out that textbooks containing effective visual aids assist students' learning process and those without visual aids negatively affect learning. Kabapınar (2003) claims that visual aids depending on their functions assist students in revealing and using their existing thinking styles and determining their interpretation styles of new information. Besides the emphasis on the importance of using visual aids Işık (2008), Alpan (2004), Yalın (1996) and Eşgi (2005) stated that teachers do not prefer visual aids as for the priority order in the use of textbooks.

When the curricula of different levels of education are examined some sort of inadequacies and unnecessary repetitions can be observed for many of the textbooks used throughout the learning lives. These books without any positive effects on student achievement drags their readers to rote learning and incuriousness. In order to increase effectiveness in education, to assist schools in reaching their objectives and 
to create positive effects on student achievement it is considered as necessary and beneficial to organize textbooks in line with today's conditions and requirements and to conduct research studies on textbooks.

Prose learning, in relation to a course presented with visual or audio method is a method of learning where abstracting, level, scheme, regression, material organization, question and visual order principles are considered. Abstracting means that students' efforts to learn information about the main idea rather than details in a text. Level refers to learning and remembering certain information from a text. According to the scheme principle, people use their own narrative forms to understand new information. Students' trends on syllogizing about cause and effect relation to the text is the regression principle. Material organization is the organization of the subjects included in the textbooks around general principles. Supporting the subjects with pictures and figures in prose learning is the principle of visual order. When the studies on the textbooks are examined, it is determined that the texts are prepared based on abstraction, level, schema, shift, material organization, exercise and also the visual order principles increase motivation.

Thompson and Wiggins (1988) emphasized in his study that the textbooks in which main themes are emphasized, supported with pictures, main and sub-topics are consistent, there are concepts in chapter beginnings and questions at the end are better learned. Tyree (1994) stated that text comprehensibility is affected by readability, subjects' being attractive and sense-making strategies of students besides the organizers. Alpan (2004) stated that a well-organized text is more suspenseful for a reader. The idea that textbooks are designed according to students means that learning experiences and outcomes meet the needs of the students. In books, it is important to give general principles and concepts first and detailed information later.

\section{Purpose of the Research}

In this study, the importance of organizing textbooks according to the principles of learning is emphasized in order to increase the effectiveness of education. It was aimed to find out whether there is a meaningful difference in total level and in information, comprehension, practical levels and in terms of permanent behavior change between books with and without questions prepared according to student's achievement and prose learning principles and utilization of traditional textbook. The study aimed to understand whether there is a significant difference in the level of knowledge, comprehension, application level and permanent behavioral change between the use of traditional textbook and the books which were prepared according to the principles of student success and text learning. The study was initiated with the assumption that textbooks prepared in accordance with prose learning principles would be more efficient.

There is a meaningful difference between the total achievements of the group for whom the textbook was prepared in accordance with prose learning principles in high school psychology course and the group for whom the textbook was supported with questions and also was written in accordance with these procedures and the group where traditional textbook was applied in terms of;

- their total achievement,

- their knowledge level,

- comprehension level achievement,

- application level achievement and

- permanent behavior change (recall).

\section{Study Group}

\section{Method}

The research model is an experimental study using the pretest-posttest control group experimental design. The population of the study consisted of 114 students from Ankara Cebeci Atatürk Vocational High School of Health and the sample of the study consisted of 114 students who were in the second grade of the same high school, taking the psychology course and who agreed to participate in the study. The study was conducted on three groups, each consisting of 38 students.

While the textbook prepared in accordance with prose learning principles but with no questions other than trail test was applied to one of the experimental groups and the textbook which was also prepared in accordance with these principles however supported with questions in each subsection was applied to the other experimental group. Meanwhile, the control group followed the traditional textbook. The Traditional 
textbook is the textbook which was decided to be taught in courses by Ministry of National Education and is widely used in Turkey.

\section{Limitations}

- The study was limited to a period reserved for data obtained as a result of achievement test and target behaviors intended to be gained for the students from the Motivation and Perception chapters selected to implement prose learning principles in psychology textbook,

- "Prose Learning" with its given definitions in the study,

- Students attending high school psychology classes and period when the course was given.

In the study, three groups that were equalized according to the variables of reading comprehension and pre-test scores, were formed; namely the one with questions, the one without questions, and the one that followed the traditional textbook. The students were randomly assigned to the groups. In terms of these variables, one-way analysis of variance was performed among the groups to observe the difference; however, no difference was found. In order to determine the level of reading comprehension of the students, who were not different from each other in terms of age, gender and the lessons taken in these three groups, the verbal ability test was applied. Practices for two chapters selected in the book are presented below as Table 1 and Table 2.

Table 1.

Test Pattern Motivation.

\begin{tabular}{|c|c|c|c|c|c|}
\hline Groups & Test & Empiric Process & Test & Time 6 Weeks & Test \\
\hline G1 & T1 & Without questions & T2 & No process & T3 \\
\hline G2 & $\mathrm{T} 2$ & With question & $\mathrm{T} 2$ & & T3 \\
\hline G3 & T3 & Traditional Textbook & $\mathrm{T} 2$ & & T3 \\
\hline
\end{tabular}

G1, G2 illustrate test groups and G3 illustrates control groups. Pre-test was applied to each three groups before the process. The test used, was illustrated as $t$ in the patterns.

Table 2.

Test Pattern Perception.

\begin{tabular}{lllllc}
\hline Groups & Test & Empiric Process & Test & Time 6 Weeks & Test \\
\hline G1 & T1 & Without question & T2 & No process & T3 \\
G2 & T2 & With question & T2 & T3 \\
G3 & T3 & Traditional Textbook & T2 & T3 \\
\hline
\end{tabular}

In the analyses, the differences between the average scores of knowledge, comprehension, application level and total achievement scores of the test scores and cognitive area of all 3 groups were examined. Also, in order to see the difference between groups in terms of permanent behavioral change, the difference between the above mentioned levels of cognitive domain and the mean of total achievement scores were also observed.

\section{Data Collection Tool}

In the research, the achievement test prepared by the researcher to in accordance with the target behaviors at the levels of knowledge, comprehension and application regarding the motivation and perception chapters of the psychology textbook to be used as the process material and text evaluation scale covering the principles of learning from the prose were used. Opinions of the instructors and students were taken about the prepared texts. In the curriculum, goals written from knowledge level to application level were transformed into observed student behaviors. The objectives were expressed in a way to cover behavioral characteristics, and then the measurement tools were developed based on these behaviors.

At the level of knowledge, there are questions that give students the opportunity to display or write about the properties of any object, and the information goes from concrete to abstract. At the level of comprehension, students should be able to translate and interpret the information they obtained in the previous stage. Being able to see the similarities and differences between the relationships is the desired behaviors at this level. In the application step, the student is expected to solve a new problem based on the objectives at knowledge and comprehension levels. At this level, the students are expected to apply the principles and generalizations to the new situations in relation to the issues of motivation and perception. In 
the traditional high school psychology textbook used as a textbook in the research, there are no principles and concepts at the beginning. There are few discussion and review questions at the end of the topic. At the end of the subject, there are no test questions measuring the achievement of the behaviors desired to be gained in the section. The prepared textbook carries these qualities. In the research, it was seen that the classification of the target behavior was a valid classification in terms of the scope when the psychology textbook was analyzed according to the target behaviors in terms of motivation and perception.

Two separate achievement tests and an evaluation scale to evaluate the text covering prose learning principles were prepared in order to gather these data. In the study, education status for motivation and perception subjects of the psychology textbook were analyzed. Classification of the target behavior determined as a result of analyses was found to be a valid classification in terms of scope. Then the targets were listed starting from the knowledge level to the application level. Then a separate table of specification was prepared for both sections and the number of questions in these tables were shown according to the weight of the behaviors covered by the targets. In the scope of the validity of achievement tests, the experts who were consulted in the determination of the target behaviors were reconsulted and opinions of five psychology experts were taken by reflecting the behaviors of the items covered by the tests within the framework of the subjects specified in the psychology course and being independent of each other for adequate sampling, items that reached consensus up to $75.00 \%$ were sorted in terms of knowledge, comprehension and application levels and two separate trial forms each compromising 70 items were prepared and trial applications were delivered to a group given psychology course and test and test score analysis were made according to application results and by taking advantage of the table of specification 40 test items were selected without harming the test's scope validity and achievement tests were created. KR20 reliability coefficient of the tests was $r x=.83$ in the motivation unit and $r x=.85$ for perception.

\section{Analysis of Data}

Chapter 1 prepared without questions was applied to 1st Group and the text supported by questions was applied to 2nd Group and the control group was delivered the traditional psychology textbook being currently read. Chapters were completed within 6 course hours in three weeks. Teaching was carried out under the supervision of a psychology teacher, but without teacher's contribution. During the learning experiences, students were not applied to variables such as feedback, correction, reinforcer, clues and verbal explanation. Direct teaching was done from books. Students summarized their work on the paper to support their self-study throughout their learning experiences and used their own learning methods. The students' self-definitions illustrating how they studied when the chapters were completed was evaluated by the researcher. Materials prepared during the empiric process were distributed to the students at the beginning of each lesson and were collected at the end of the lesson together with the study notes. The researcher tried to keep realization of the process under predetermined conditions. He also attended the classes regularly and filled out an observation form for his students from time to time. At the end of the study, the students in test and control groups, also presented short information about the textbooks with written materials they currently use. Students' responses to the follow-up test (Motivation; 25, Perception; 20 questions) at the end of the chapters were evaluated.

In this study, the pre- and post-test scores of the students in the experimental and control groups and the knowledge, comprehension, application and total achievement scores were obtained in terms of permanent behavior change.

The tests were applied three times to the students who formed the experimental and control groups in order to obtain the pre-test, post-test and recall test measures. Two other practitioners were employed in the test applications. It was observed that the 40-minute-period given for the application was sufficient. In the research, the experimental groups and the control group that read the traditional textbook did not read the texts prior to lessons uncontrolled variables affected groups equally.

Testing procedure in course hours were completed by ensuring regular attendance of students to school in application days. In the 1st subject in order to observe cognitive field's difference between achievement averages in knowledge, comprehension, application and in total level the difference between averages of pretest score and final-pre-test scores were analyzed and for the permanence, the difference between achievement averages between 3 rd test and final test was examined. The same application was made separately for the perception unit. The significance level was taken as $p<.01$ in the statistical analyses. Since the groups were independent from each other, one-way analysis of variance was conducted in all three groups to analyze the effect of the textbooks on the three levels of cognitive domain and the effect on the overall 
achievement. As a result of this procedure $F$ values were found meaningful. When the difference between the average of the pre-test results and the mean of the last test was examined with the variance analysis, there was a significance level of .01 between the groups and the independent $t$ test was used.

\section{Results}

In this section, the data collected about the samples and assumptions were analyzed by using appropriate statistical techniques and presented as charts. The results of the one-way analysis of variance for the students' reading comprehension and pre-test scores were examined and as a result no significant difference was found between comprehension test average of three groups. In light of this information, it can be claimed that groups are equivalent in terms of this variable. Similarly, there was no significant difference between the pre-test scores of all three groups. Considering the findings related to the evaluation of the prepared text, the results obtained from the scale study are presented below separately for the instructors and students.

\section{Findings on the Evaluation of the Prepared Text}

Table 3.

Average Points Given by Instructors to Questions Asked for Evaluation of Prepared Text

\begin{tabular}{lcrr}
\hline & Average Points & & \\
\cline { 2 - 3 } & $\mathbf{N}$ & $\mathbf{X}$ & S.D. \\
\hline Form & 7 & 14.57 & .78 \\
Subject delivery and quality & 7 & 33.14 & 2.11 \\
Convenience for student & 7 & 14.57 & .53 \\
Text layout & 7 & 58.14 & 2.26 \\
\hline
\end{tabular}

When Table 3 is examined, it can be claimed that with these results, form of the prepared textbooks, delivery and the quality of subjects, suitability for the students and the text layout were found sufficient by instructors.

Table 4.

Average Points by the Students to the Questions Directed for the Evaluation of the Prepared Text.

\begin{tabular}{lcrr}
\hline & Average Scores & & \\
\cline { 2 - 4 } & $\mathbf{N}$ & X & S.D. \\
\hline Form & 76 & 14.10 & .90 \\
Subject delivery and quality & 76 & 33.01 & 1.57 \\
Convenience for student & 76 & 14.26 & .91 \\
Text layout & 76 & 59.27 & 1.53 \\
\hline
\end{tabular}

With this result, it can be claimed that form of the prepared textbooks, delivery and the quality of subjects, suitability for the students and the text layout were found sufficient by the students.

\section{Findings on Motivation}

Groups and Total Level of Achievement

Table 5.

Variance Analysis for Achievement Score of Groups in Motivation Unit Total Level.

\begin{tabular}{lrrrr}
\hline Variance Source & Total Squares & Freedom Degree & Average Squares Total & F \\
\hline Intergroup & 874.32 & 2 & 437.16 & $70.62^{*}$ \\
Intragroup & 686.12 & 111 & 6.18 & \\
Total & 1561.24 & & & \\
\hline
\end{tabular}

$\mathrm{p}<.01$

According to the results of analysis of variance, as seen in Table 5, there is a significant difference between the total achievement scores of the groups at a level of .01. $t$ test was applied to determine among which groups this difference originated from. These data are shown in Table 6. 
Table 6.

Motivation Unit Total Level Achievement Scores and $t$ Values of the Groups.

\begin{tabular}{lrrrrrr}
\hline Groups & $\mathbf{N}$ & $\mathbf{X}$ & Achievement X & Achievement S & t without question & Traditional t \\
\hline With question & 38 & 23.44 & 1 to $2=1.66$ & 1 to $3=.57$ & 23.72 & $124.00^{*}$ \\
Without question & 38 & 21.78 & 2 to $3=5.70$ & 2 to $3=.59$ & - & $81.43^{*}$ \\
Traditional & 38 & 15.00 & 1 to $3=7.44$ & 1 to $3=.54$ & - & - \\
\hline
\end{tabular}

$* p<.05$

According to data in Table 6, it can be claimed that there is a significant difference between the groups in terms of total achievements at .05 significance level and "74" freedom rate. According to these results, it is possible to claim that textbooks prepared according to the prose learning principles with questions and the textbooks prepared without questions had a significant effect on total level of achievement when compared to traditional books. The fact that this difference is seen in favor of the group receiving textbook with questions can be attributed to the fact that the questions significantly affected the total achievement scores.

\section{Groups and Achievement in Knowledge Level}

Table 7.

Variance analysis for Groups' Motivation Unit Knowledge Level Achievement Scores.

\begin{tabular}{lrrrr}
\hline Variance Source & Squares Total & Freedom Rate & Average Squares Total & F \\
\hline Intergroup & 68.96 & 2 & 34.48 & $6.54^{*}$ \\
Intragroup & 584.97 & 111 & 5.27 & \\
Total & 653.93 & & & \\
\hline
\end{tabular}

$* p<.01$

According to the variance analysis results as can be seen in Table 7, there is a significant difference at .01 level between groups' knowledge level achievement scores t test was applied to determine among which groups this difference originated from. These data are shown in Table 8.

Table 8.

Motivation Unit Knowledge Level Achievement Scores and t Values of the Groups.

\begin{tabular}{lrrrrrr}
\hline Groups & $\mathbf{N}$ & $\mathbf{X}$ & Achievement X & Achievement S & t without question & Traditional t \\
\hline With question & 38 & 10.18 & 1 to $2=.58$ & .39 & $14.50^{*}$ & $41.60^{*}$ \\
Without question & 38 & 9.60 & 2 to $3=1.50$ & .44 & - & $30.00^{*}$ \\
Traditional & 38 & 2.10 & 1 to $3=2.08$ & .45 & - & - \\
\hline
\end{tabular}

$* p<.05$

According to data in Table 8, it can be claimed that there is a significant difference between the groups in terms of knowledge level achievements at .05 significance level and "74" freedom rate. According to these results, it is possible to claim that textbooks prepared according to the prose learning principles with questions and the textbooks prepared without questions had a significant effect on knowledge level achievement when compared to traditional books. The fact that this difference is seen in favor of the group receiving textbook with questions can be attributed to the fact that the questions significantly affected the total achievement scores.

\section{Groups and Achievement in Comprehension Level}

Table 9.

Variance analysis for Groups' Motivation Unit Comprehension Level Achievement Scores.

\begin{tabular}{lrrrr}
\hline Variance Source & Squares Total & Freedom Rate & Average Squares Total & F \\
\hline With question & 46.96 & 2 & 23.48 & $7.41^{*}$ \\
Without question & 350.97 & 111 & 3.16 \\
Total & 397.93 & & & \\
\hline
\end{tabular}

$p<.01$ 
The $\mathrm{F}$ value according to the variance analysis results shows that there is a significant difference between comprehension level achievements among the groups at .01 level t test was applied to determine among which groups this difference originated from. These data are shown in Table 10.

Table 10

Motivation Unit Comprehension Level Achievement Scores and t Values of the Groups.

\begin{tabular}{lrrrrrr}
\hline Groups & $\mathbf{N}$ & $\mathbf{X}$ & Achievement X & Achievement S & t without question & Traditional t \\
\hline With question & 38 & 5.07 & 1 to $2=.35$ & .37 & $8.75^{*}$ & $41.25^{*}$ \\
Without question & 38 & 5.42 & 2 to $3=2.00$ & .34 & - & $50.00^{*}$ \\
Traditional & 38 & 3.42 & 1 to 3 $=1.65$ & .31 & - & - \\
\hline
\end{tabular}

$* \mathrm{p}<.05$

According to data in Table 10, it can be claimed that there is a significant difference between the groups in terms of comprehension level achievements at .05 significance level and "74" freedom rate. According to these results, it is possible to claim that the textbooks prepared according to the prose learning principles with or without questions had a significant effect on comprehension level achievement compared to traditional books. The fact that this difference is seen in favor of the group receiving the textbook with questions can be attributed to the fact that the questions significantly affected the knowledge level achievement scores.

\section{Groups and Achievement in Practice Level}

\section{Table 11.}

Variance analysis for Groups' Motivation Unit Application Level Achievement Scores.

\begin{tabular}{lrrrr}
\hline Variance Source & Squares Total & Freedom Rate & Average Squares Total & F \\
\hline Intergroup & 202.18 & 2 & 101.09 & $18.96^{*}$ \\
Intragroup & 592.31 & 111 & 5.33 & \\
Total & 794.49 & & & \\
\hline
\end{tabular}

$\mathrm{p}<.01$

The $\mathrm{F}$ value according to the variance analysis results shows that there is a significant difference between application level achievement among the groups at .01 level t test was applied to determine among which groups this difference originated from. These data are shown in Table 12.

Table 12.

Motivation Unit Practice Level Achievement Scores and $t$ Values of the Groups.

\begin{tabular}{lrrrrrr}
\hline Groups & $\mathbf{N}$ & $\mathbf{X}$ & Achievement X & Achievement S & t without question & Traditional t \\
\hline With question & 38 & 8.23 & 1 to $2=1.52$ & .55 & $25.33^{*}$ & $62.16^{*}$ \\
Without question & 38 & 6.71 & 2 to $3=2.21$ & .50 & - & $36.83^{*}$ \\
Traditional & 38 & 4.50 & 1 to $3=3.73$ & .52 & - & - \\
\hline$*$
\end{tabular}

$* p<.05$

According to data in Table 12, it can be claimed that there is a significant difference between the groups in terms of application level achievements at .05 significance level and "74" freedom rate. According to these results, it is possible to claim that the textbooks prepared according to the prose learning principles with questions and the textbooks prepared without questions had a significant effect on application level achievement when compared to traditional books. The fact that this difference is seen in favor of the group receiving the textbook with questions can be attributed to the fact that the questions significantly affected knowledge level achievement scores.

\section{Groups and Retention (Permanent Change in Behavior)}

Table 13.

Variance Analysis for Groups' Motivation Unit Total Level Permanency Scores.

\begin{tabular}{lrrrr}
\hline Variance Source & Squares Total & Freedom Rate & Average Squares Total & F \\
\hline Intergroup & 1370.01 & 2 & 685.00 & $96.75^{*}$ \\
Intragroup & 785.92 & 111 & 7.08 & \\
Total & 2155.93 & & & \\
\hline
\end{tabular}


The $\mathrm{F}$ value according to the variance analysis results shows that there is a significant difference between total level permanency scores among the groups at .01 level t test was applied to determine among which groups this difference originated from. These data are shown in Table 14.

Table 14.

Motivation Unit Total Level Retention Scores and $t$ Values of the Groups.

\begin{tabular}{lcccrrr}
\hline Groups & $\mathbf{N}$ & $\mathbf{X}$ & Achievement X & Achievement S & t without question & Traditional t \\
\hline With question & 38 & 22.86 & 1 to $2=2.13$ & .62 & $30.43^{*}$ & $136.33^{*}$ \\
Without question & 38 & 20.73 & 2 to $3=6.05$ & .65 & - & $86.43^{*}$ \\
Traditional & 38 & 14.68 & 1 to $3=8.18$ & .54 & - & - \\
\hline
\end{tabular}

$* p<.05$

\section{Findings on Perception}

\section{Groups and Total Level of Achievement}

Table 15.

Variance Analysis for Groups' Perception Unit Total Level Achievement Scores.

\begin{tabular}{lrrrr}
\hline Variance Source & Squares Total & Freedom Rate & Average Squares Total & F \\
\hline Intergroup & 683.38 & 2 & 341.69 & $35.63^{*}$ \\
Intragroup & 1062.05 & 111 & 9.57 & \\
Total & 1745.43 & & & \\
\hline
\end{tabular}

$p<.01$

The $F$ value found, shows us that there is a significant difference between significance level total achievements. $t$ test was applied to determine among which groups this difference originated from. These data are shown in Table 16.

Table 16.

Perception Unit Total Level Achievement Scores and $t$ Values of the Groups.

\begin{tabular}{lcccrrr}
\hline Groups & $\mathbf{N}$ & $\mathbf{X}$ & Achievement X & Achievement S & t without question & Traditional t \\
\hline With question & 38 & 10.76 & 1 to $2=2.53$ & .69 & $31.25^{*}$ & $74.75^{*}$ \\
Without question & 38 & 8.23 & 2 to $3=3.45$ & .73 & - & $41.12^{*}$ \\
Traditional & 38 & 4.78 & 1 to $3=5.98$ & .70 & - & - \\
\hline$*$
\end{tabular}

According to data in Table 16, it can be claimed that there is a significant difference between the groups in terms of total level achievement at .05 significance level and " 74 " freedom rate. According to these results, it is possible to claim that the textbooks prepared according to the prose learning principles with questions and the textbooks prepared without questions had a significant effect on total level achievement when compared to traditional books. The fact that this difference is seen in favor of the group receiving the textbook with questions can be attributed to the fact that the questions significantly affected knowledge level achievement scores.

\section{Groups and Achievement in Knowledge Level}

Table 17.

Variance Analysis for Groups' Perception Unit Information Level Achievement Scores.

\begin{tabular}{lcccc}
\hline Variance Source & Squares Total & Freedom Rate & Average Squares Total & F \\
\hline Intergroup & 140.13 & 2 & 70.07 & $22.24^{*}$ \\
Intragroup & 349.81 & 111 & 3.15 & \\
Total & 489.93 & & & \\
\hline $\mathrm{p}<.01$ & & & &
\end{tabular}

$\mathrm{p}<.01$ 
The $\mathrm{F}$ value according to the variance analysis results shows that there is a significant difference between groups for information level achievement at .01 level t test was applied to determine among which groups this difference originated from. These data are shown in Table 18.

Table 18.

Perception Unit Knowledge Level Achievement Scores and t Values of the Groups.

\begin{tabular}{lcccrrr}
\hline Groups & $\mathbf{N}$ & $\mathbf{X}$ & Achievement X & Achievement S & t without question & Traditional t \\
\hline With question & 38 & 3.97 & 1 to $2=5.39$ & .40 & $107.80^{*}$ & $41.60^{*}$ \\
Without question & 38 & 1.42 & 2 to $3=.47$ & .42 & - & $9.40^{*}$ \\
Traditional & 38 & 1.89 & 1 to $3=2.08$ & .47 & - & - \\
\hline
\end{tabular}

$* \mathrm{p}<.05$

According to data in Table 18, it can be claimed that there is a significant difference between the groups in terms of knowledge level achievement at .05 significance level and " 74 " freedom rate. According to these results, it is possible to claim that the textbooks prepared according to the prose learning principles with our without questions had a significant effect on knowledge level achievement when compared to traditional books. The fact that this difference is seen in favor of the group receiving the textbook with questions can be attributed to the fact that the questions significantly affected knowledge level achievement scores.

\section{Groups and Achievement in Comprehension Level}

Table 19.

Variance Analysis for Groups' Perception Unit Comprehension Level Achievement Scores.

\begin{tabular}{lrrrr}
\hline Variance Source & Squares Total & Freedom Rate & Average Squares Total & F \\
\hline Intergroup & 130.59 & 2 & 65.30 & $12.85^{*}$ \\
Intragroup & 564.42 & 111 & 5.08 & \\
Total & 695.01 & & & \\
\hline $\mathrm{p}<.01$ & & & &
\end{tabular}

The $\mathrm{F}$ value according to the variance analysis results shows that there is a significant difference between groups for comprehension level achievement at .01 level t test was applied to determine among which groups this difference originated from. These data are shown in Table 20.

Table 20.

Perception Unit Comprehension Level Achievement Scores and $t$ Values of the Groups.

\begin{tabular}{lcccrrr}
\hline Groups & $\mathbf{N}$ & $\mathbf{X}$ & Achievement X & Achievement S & t without question & Traditional t \\
\hline With question & 38 & 3.47 & 1 to $2=.21$ & .49 & $3.50^{*}$ & $47.40^{*}$ \\
Without question & 38 & 3.26 & 2 to $3=2.16$ & .58 & - & $30.85^{*}$ \\
Traditional & 38 & 1.10 & 1 to $3=2.37$ & .46 & - & - \\
\hline
\end{tabular}

$* p<.05$

According to data in Table 20, it can be claimed that there is a significant difference between the groups in terms of comprehension level achievement at .05 significance level and " 74 " freedom rate. According to these results, it is possible to claim that the textbooks prepared according to the prose learning principles with or without questions had a significant effect on comprehension level achievement when compared to traditional books. The fact that this difference is seen in favor of the group receiving the textbook with questions can be attributed to the fact that the questions significantly affected knowledge level achievement scores.

\section{Groups and Achievement in Practice Level}

Table 21.

Variance Analysis for Groups' Perception Unit Application Level Achievement Scores.

\begin{tabular}{lrrrr}
\hline Variance Source & Squares Total & Freedom Rate & Average Squares Total & F \\
\hline Intergroup & 36.70 & 2 & 18.35 & $4.37^{*}$ \\
Intragroup & 465.86 & 111 & 4.20 & \\
Total & 502.56 & & & \\
\hline $\mathrm{p}<.01$ & & & &
\end{tabular}


The $\mathrm{F}$ value according to the variance analysis results shows that there is a significant difference between groups for application level achievement at .01 level $t$ test was applied to determine among which groups this difference originated from. These data are shown in Table 22.

Table 22.

Perception Unit Practice Level Access Points and $t$ Values of the Groups.

\begin{tabular}{lcccrrr}
\hline Groups & $\mathbf{N}$ & $\mathbf{X}$ & Achievement X & Achievement S & t without question & Traditional t \\
\hline With question & 38 & 3.34 & 1 to $2=.48$ & .49 & $8.00^{*}$ & $27.40^{*}$ \\
Without question & 38 & 2.86 & 2 to $3=.89$ & .54 & - & $14.63^{*}$ \\
Traditional & 38 & 1.97 & 1 to $3=1.37$ & .42 & - & - \\
\hline
\end{tabular}

$* p<.05$

According to data in Table 22, it can be claimed that there is a significant difference between the groups in terms of application level achievement at .05 significance level and "74" freedom rate. According to these results, it is possible to claim that the textbooks prepared according to the prose learning principles with or without questions had a significant effect on comprehension level achievement when compared to traditional books. The fact that this difference is seen in favor of the group receiving the textbook with questions can be attributed to the fact that the questions significantly affected knowledge level achievement scores.

Groups and Retention (Permanent Change in Behavior)

Table 23.

Variance Analysis for Groups' Perception Unit Total Level Permanency Scores

\begin{tabular}{lrrrr}
\hline Variance Source & Squares Total & Freedom Rate & Average Squares Total & F \\
\hline Intergroup & 1145.07 & 2 & 572.54 & $57.20^{*}$ \\
Intragroup & 1111.18 & 111 & 10.01 & \\
Total & 2256.25 & & & \\
\hline
\end{tabular}

$p<.01$

According to the results of variance analyses, it is observed that there is a significant difference at .01 significance level between groups' total level permanency scores. $t$ test was applied to determine among which groups this difference originated from. These data are shown in Table 24.

Table 24.

Perception Unit Total Level Retention Scores and $t$ Values of the Groups.

\begin{tabular}{lcccrrr}
\hline Groups & $\mathbf{N}$ & $\mathbf{X}$ & Achievement X & Achievement S & t without question & Traditional t \\
\hline With question & 38 & 26.23 & 1 to $2=3.87$ & .69 & $48.37^{*}$ & $86.22^{*}$ \\
Without question & 38 & 22.36 & 2 to $3=3.89$ & .74 & - & $43.22^{*}$ \\
Traditional & 38 & 18.47 & 1 to $3=7.76$ & .74 & - & - \\
\hline
\end{tabular}

$* p<.05$

According to the date given in Table 24, it is possible to claim that it significantly affected the achievement in total level between the groups at .05 significance level and " 74 " freedom rate. According to these results, it is possible to claim that the textbooks prepared according to the prose learning principles with or without questions had a significant effect on total achievement when compared to traditional books. The fact that this difference is seen in favor of the group receiving the textbook with questions can be attributed to the fact that the questions significantly affected the total achievement scores.

The findings supported the assumptions that textbooks are more effective when prepared in line with prose learning principles among the groups in terms of total achievements knowledge, comprehension, application and permanent behavior change in the beginning of the study.

There is a significant difference among total achievements of the group in which the textbook that was prepared according to the principles of prose learning in high school psychology course and the group in which the book was supported with questions written in accordance with these principles and the group in which traditional textbook was applied and these differences are;

- Between their total achievements,

- Between knowledge levels achievements,

- Between comprehension level achievement, 
- Between application level achievement and

- In terms of permanent behavior change (recall).

Supporting the hypothesis with the findings, and supported with questions increase student success when compared to traditional books. The textbooks prepared in this way can be claimed to be effective in reinforcing the knowledge and strengthening the memorization by means of intermittent iterations, such as basic concepts, sample experiments, summaries and questions in the subject subheadings. The subjects that are organized and described in a significant manner and presented with a style attracting students' attention and the learning environments in which the learning subheading is effective on learning the whole and reinforcing learning via tests at the end of subjects can be more persistent.

\section{Discussion, Conclusion and Implications}

In this study, which was conducted to evaluate the effects of textbooks that were prepared in line with prose learning principles without questions and textbooks written with these principles and also supported with questions on student achievement when compared to traditional textbooks;

1. It was observed that the textbooks prepared in line with prose learning principles with or without questions were more effective on total achievement when compared to traditional textbook. This effect was mostly in favor of the group using the textbook with questions.

2. It was determined that the textbooks prepared in line with prose learning principles with or without questions were more effective on knowledge level of the cognitive field when compared to the traditional textbook. This effect was mostly in favor of the group using the textbook with questions.

3. It was observed that the textbooks prepared in line with prose learning principles with or without questions were more effective on students' comprehension level achievements when compared to the traditional textbook. The significant difference observed among the groups in Unit 1 (Motivation) is found to be in favor of the group using the textbook without questions.

4. It was observed that the textbooks prepared in line with prose learning principles with or without questions were more effective on students' application level when compared to the traditional textbook. This effect was mostly in favor of the group using the textbook with questions.

5. It was observed that the textbooks prepared in line with prose learning principles with or without questions were more effective on students' total achievement in terms of permanency when compared to the traditional textbook.

The significant difference especially observed in favor of the group with questions when compared to the group studying traditional textbook prepared in accordance with prose learning principles and supported with and without questions can be attributed to questions prepared both in accordance with prose learning principles and knowledge, comprehension, application levels of the cognitive field. Bloom, Englehart, Furst, Hill and Krathwohl (1956) mentioned three types of learning as cognitive, affective and psycho-motor. Based on the level of learning, these areas are divided into sub-headings. In the study, the reasons of studying the first three steps in the conventional taxonomy of Bloom et al. (1956) in the level of knowledge, comprehension, application, analysis, synthesis and evaluation can be explained by the gradual ordering of the desired behaviors in education from simple to complex and the learning at these levels is a prerequisite for high level cognitive learning. The results of this study investigating the effects of text learning principles on knowledge, comprehension and application levels may contribute to the preparation of new textbooks for the levels of analysis, synthesis and evaluation.

The fact that textbooks prepared in accordance with prose learning principles were more effective on students' total achievement in terms of permanency when compared to the traditional textbook and the significant difference observed among the groups in favor of the group using the textbook with questions emphasize the importance of supporting visual order and knowledge with exercises prepared according to prose learning principles in textbooks. Bodur (2016) emphasizes that text and image complement each other in books and that the topics are understood more easily by supporting the scripts with visual elements.

Dündar (1995); Ergin and Gözütok (1996) emphasized that no place was given in teachers' textbooks to visual aids attracting student's attention and giving interesting information. They also stated that the preparation and printing phases for the textbook should be reviewed by experts. Kabapınar (2001) compared Turkish and British Science books in terms of visual elements and found that visual aids used in British 
textbooks are three times more than the visuals used in Turkey. Şahin (2004) stated that the texts included in the book became attractive with visual aids. In his study, Coşkun (2003) emphasized the importance of supporting the content with pictures, photographs, graphics, tables and figures. Duman (2003) specified the importance of preparing book content as up-to-date, objective, directing individual to thinking rather than memorization and enabling problem solving, discovering and developing critical thinking and in compliance with principles of prose learning.

Çerçi (2016) emphasized the books' basic role in education along with its essential elements as purpose, content, teacher-student responsibility and as questions. As it can be seen in these studies that when textbooks are arranged in line with prose learning principles, student success increases textbooks should be arranged very well in terms of content, expression, visuality and teaching. Prose learning principles are very important to complement these characteristics.

Since there is a result in the study that textbooks prepared according to prose learning principles have more effect on total achievement when compared to traditional textbook, teachers should use books based on these principles in order to increase student achievement and efficiency in education during their learning experiences.

Since the effects of textbooks with and without questions prepared according to the prose learning principles are more than the traditional textbooks on cognitive field's information, comprehension, application levels, the s efficiency of the subjects in the secondary school textbooks should be evaluated separately within the framework of the targets at these levels.

Since the textbooks prepared according to prose learning principles had more effect on students' total comprehension level achievement when compared to traditional textbook, students should be given opportunities to give examples based on behaviors, e.g., interpretation, giving examples based on the knowledge they obtained in knowledge step via course notes during their studies.

Since it was observed that the textbooks prepared according to prose learning principles without questions and textbooks supported with questions had more effect on students' application level achievements when compared to the traditional textbook, the objectives of the sections in the books used in psychology and other courses in secondary education should be revised based on the principles of prose learning and students should be given opportunities to use the problem solving pattern for each course.

Since the textbooks prepared according to prose learning principles without questions and the textbooks supported with questions had significant effect on students' total achievements in terms of recalling when compared to the traditional textbook according to these principles, the exercises increasing the permanence of learning should be prepared carefully while organizing the textbook.

Textbooks should be renewed by making arrangements taking into account of the changing objectives through in curriculum development studies rather than traditional methods based on memorization.

New studies on textbooks covering prose learning principles can be conducted on wider groups and at different class levels. New studies investigating the effects of books based on these principles within longer periods of time should be organized. Activities in textbooks should enhance the cognitive solicitation level.

Studies about prose learning principles that have already determined to have effects on knowledge, comprehension, application levels of cognitive field should also be carried out at the levels of analysis, synthesis and evaluation phases to find out whether they will be effective or not. 


\section{TÜRKÇE SÜRÜM}

\section{Giriş}

Eğitim, hedefleri belirlenmiş uygulamaları içeren istendik davranışları kazandırma çalışmalarıdır. Bolat (2014), öğrenme yaşantılarının düzenlenmesinde en önemli unsurun eğitim programları olduğunu belirtmiştir. Diğer önemli faktör olan ders kitabı, öğrencinin öğrenme yaşantılarına temel olan, yazılı ve basılı gereçler grubunda yer alan çalışma materyalidir. Özellikle metinden öğrenmede, ders kitabı önemli rol oynamaktadır.

Alan yazında öğrenmede metnin rolüne yönelik farklı görüşlerle karşılaşılmaktadır. Bir görüşe göre metin öğrencinin gelişimini ve değişimini sağlayan dinamik bir güçtür. Bir başka çalışmaya göre, metin daha çok ezberlenir. Bu ezberleme öğrenci-öğretmen etkileşimini yönlendirir. Ayrıca öğrenciler yorum katmadan metni olduğu gibi öğrenmeye çalışırlar. Ders kitaplarının metin tasarımında öğrencinin düzeyi, ilgileri, beklentileri, algılama biçimi gibi özelliklerinin, tanımlanması gereklidir. 20. yüzyılda ders kitapları öğretimde önemli görülürken, günümüzde bu konuda farklı görüşler paylaşılmaktadır, Öğrenme yaşantılarının hazırlığında, öğretim materyali olarak ders kitaplarının artık öneminin azaldığı, yeni teknolojilere uygun hazırlanmış öğretim materyallerinin, bilgisayarla öğretimin daha önemli olacağını savunan çalışmalar da bulunmaktadır. Eğitimde yeni teknolojilerin kullanımı, geleneksel yönteme göre daha fazla duyu organının etkileşimde bulunması sonucu eğitim öğretim faaliyetlerini kolaylaştırmaktadır (Balaman, 2016; Balaman \& Tüysüz, 2011; Yanpar, 2006).

Soong ve Yager (1993) çalışmalarında, öğrencilerin büyük bir kısmının bütün bilgilerin kaynağı olarak ders kitabını gördüklerini, aynı şekilde ders kitaplarından yararlanılmadığında öğrenci, velilerinin de bu duruma tepki gösterdiklerini vurgulamışlardır. Ünal ve Pideci (2000), ders kitaplarının, öğrencilerin derse hazırlıklı gelebilmesi, geniş bilgilere özet halde ulaşabilmesi, ödev ve grup çalışmalarında ortak kullanılabilmesi gibi imkânlar sağladığını belirtmişlerdir. Demirel (1999) öğrencilerin, müfredat programı ile hedeflenen niteliklere ulaşmasında ders kitaplarının önemini vurgulamış, eğitim-öğretim sürecinde yer alan görsel araçlar içinde en fazla kitapların kullanıldığını belirtmiştir. Bir dersin hedefleri belirlenip, onların göstergesi olan davranışlar tanımlandıktan sonra eğitim durumları düzenlenmesi aşamasında, bu davranışların kazanımı için kullanılacak araç ve gereçlerin seçimi önemlidir. Bunlar arasında önemli bir yeri olan ders kitabının nitelikli olma zorunluluğu vardır. Aslantaş ve Demirci (2016) çocukların öğrendiklerini uygulamalarında, yaratıcılıklarının gelişmesinde ders kitaplarının önemli olduğunu bu nedenle, ders kitaplarının bazı niteliklere sahip olmasının gereğini vurgulamışlardır.

Ders kitaplarının öğretme-öğrenme ortamında amacına hizmet etmesi için bazı özelliklere sahip olması gerekmektedir. Ünsal ve Güneş (2003), bir ders kitabının başarısını genel olarak, fiziksel özellikler içerik-sunum sıralaması, görsel sunum dil, anlatım gibi temel kriterlerin incelenmesiyle anlaşıldığını belirtmektedirler. Arslan ve Özpınar (2009) ise çalışmalarında ders kitaplarını incelemek için öğretim programına uygunluğu, hazırlık çalışmaları, ölçme değerlendirme, bilimsel içerik, dil ve anlatım, görsel düzen, tasarım ilke ve öğeleri başlıklarını dikkate almışlardır.

Yalın (1996) da ülkemizde genel olarak ders kitapları değerlendirilirken öncelikle kitabın içeriğinin dikkate alınan unsur olduğunu belirtmiştir. Ders kitaplarında öğrencinin öğrenmeye motivasyonu, başarısı bakımından metindeki bilgilerin öğrenilme durumunu arttıran görsel düzenin kullanımı çok önemlidir. Görsel öğeler, öğrencide ilgili kavramın soyutluktan kurtarılmasını ve süreçlerin anlamlandırılmasını sağlamaktadır. Dursun ve Eşgi (2008); Kibarkaya (1996), ders kitaplarındaki görsel öğelerin öğrencilere bilgiyi verme, bilgileri destekleme, ilgi çekerek dikkati yönlendirme, konuları özetleme, olgular veya kavramlar arasındaki ilişkileri gösterme, zihinde canlandırılması güç olan karışık konuları daha kolay anlaşılır kılma gibi çok önemli işlevleri olduğunu vurgulamışlardır.

Yeşilyurt ve Gül (2008); Yıldıran (2007); Altunoğlu ve Atav (2005), çalışmalarında ders kitaplarının görsel öğeler açısından değerlendirilmesinin ihmal edildiğini ve kitapların bu yönden yetersiz olduğunu açıklamışlardır. Özay ve Hasenekoğlu (2007); Yalın (1996); Güneş (2002); Kabapınar (2003) çalışmalarında, etkili görsel öğeler içeren ders kitaplarının öğrencilerin öğrenmelerine yardımcı olduğunu, olmayanların da öğrenmeyi olumsuz etkilediğini göstermişlerdir. Kabapınar (2003) yaptığı çalışmasında görsel öğelerin, işlevlerine göre, öğrencilerin var olan düşünme biçimlerinin açığa çıkarılmasına, kullanılmasına ve yeni bilgiyi yorumlama biçimlerinin belirlenmesine yardımcı olduğunu söylemektedir. Görsel öğelerin kullanımının öneminin vurgusu yanında Işık (2008), Alpan (2004), Yalın (1996) ile Eşgi (2005) öğretmenlerin ders kitabı kullanımındaki öncelik sırasında, görsel öğeleri tercih etmediklerini açıklamışlardır. 
Farklı öğretim düzeylerinin ders programları incelendiğinde, öğrenme yaşantıları esnasında kullanılan ders kitaplarının çoğunda birtakım yetersizlikler, gereksiz tekrarlar görülmektedir. Öğrenci erişisi üzerinde olumlu etkisi olmayan bu kitaplar okuyanları ezberciliğe, ilgisizliğe sürüklemektedir. Eğitimde etkililiği arttırmak, okulun hedeflerine ulaşmasına yardımcı olmak, öğrenci erişsisi üzerinde olumlu etkiler yaratabilmek için, ders kitaplarının günün koşulları ve gereksinimlerine göre düzenlenmesi, bunun için de ders kitapları üzerinde araştırmalar yapılması gerekli ve yararlı görülmektedir.

Metinden öğrenme, görsel ya da işitsel biçimde sunulan bir derse ilişkin olarak, soyutlama, düzey, şema, vardama, materyal örgütlenişi, soru ve görsel düzen ilkelerinin dikkate alındığı bir öğrenme biçimidir. Soyutlama, öğrencilerin bir metinde ayrıntılardan çok, ana fikirle ilgili bilgileri öğrenmek için çaba göstermesidir. Düzey, bir metinden belli bir bilgi bölümünü öğrenme ve hatırlamayı ifade eder, Şema ilkesine göre, insanlar yeni bir bilgiyi anlamak için kendi anlatım şekillerini kullanırlar. Öğrencilerin metindeki neden - sonuç ilişkileri hakkında çıkarım yapma eğilimleri vardama ilkesidir. Materyal örgütlenişi, ders kitaplarında yer alan konuların genel ilkeler etrafında örgütlenmesidir. Metinden öğrenmede konuların resim ve şekiller ile desteklenmesi görsel düzen ilkesidir. Ders kitapları konusunda yapılan çalışmalara bakıldığında, soyutlama, düzey, şema, vardama, materyal örgütlenişi, alıştırma ve görsel düzen ilkelerini temel alarak hazırlanan metinlerin motivasyonu arttırdığı belirlenmiştir. Thompson ve Wiggins (1988) öğretimde, ana fikirlerin vurgulandığı, resimlerle desteklenen, ana ve alt başlıkların tutarlıı̆ına dikkat edilen, bölüm başlarında kavramlar, sonlarında özet ve soruların bulunduğu ders kitapları ile konuların daha iyi öğrenildiğini çalışmasında vurgulamıştır. Tyree (1994) ise metnin anlaşııılığııı; organize edicilerin yanında okunabilirlik, konunun ilginç olması ve öğrencinin anlamlandırma stratejilerinin etkilediğini belirtmiştir. Alpan (2004), çalışmasında, iyi örgütlenmiş bir metnin okur için daha sürükleyici olduğunu ifade etmiştir. Ders kitaplarının, öğrenciye göre olması, öğrenme yaşantıları ve sonucunun öğrenci gereksinimlerini karşılaması demektir. Kitaplarda, önce genel ilke ve kavramların verilmesi ve bunu ayrıntılı bilgilerin izlemesi önemlidir

\section{Araştırmanın Amacı}

Araştırmada, öğrencilerin daha başarılı olmaları dolayısıyla eğitimde etkililiği arttırabilmek için ders kitaplarının metinden öğrenme ilkelerine göre düzenlenmesinin önemi üzerinde durulmaktadır. Öğrenci başarısı ve metinden öğrenme ilkelerine göre hazırlanan sorusuz ve sorulu kitaplar ile okutulmakta olan geleneksel ders kitabının kullanılması arasında toplam düzeyde bilgi, kavrama ve uygulama düzeylerinde ve kalııı izli davranış değişikliği bakımından anlamlı bir fark olup olmadığını anlamak amaçlanmıştır. Metinden öğrenme ilkelerine göre hazırlanan ders kitaplarının belirtilen bu düzeylerde daha etkili olacağı varsayımları ile çalışmaya başlanmıştır.

Lise psikoloji dersinde, metinden öğrenme ilkelerine göre hazırlanan ders kitabının kullanıldığı grup ile bu ilkelere göre yazılan ancak sorularla desteklenmiş olan kitabın kullanıldığı grubun toplam erişileri ile geleneksel ders kitabının uygulandığı grubun;

- Toplam erişileri,

- Bilgi düzeyleri erişisi arasında,

- Kavrama düzeyi erişisi arasında,

- Uygulama düzeyi erişisi arasında ve

- Kalııı izli davranış değişikliği (hatırlama) bakımından aralarında anlamlı bir fark vardır.

\section{Yöntem}

\section{Çalışma Grubu}

Araştırma modeli, ön test-son test denk kontrol gruplu deney deseninden yararlanılarak yapılan deneysel bir çalışmadır. Çalışmanın evrenini, Ankara Cebeci Atatürk Sağlık Meslek Lisesi öğrencileri, örneklemi ise, aynı lisede 2. sınıfta öğrenim gören, psikoloji dersini almakta olan ve çalışmaya katılmayı kabul eden 114 öğrenci oluşturmuştur. Her biri 38 öğrenciden oluşan üç grup üzerinde çalışma yapılımışıı. Grupların birine, metinden öğrenme ilkelerine göre hazırlanan, ancak izleme testi dışında sorulara yer verilmeyen ders kitabı, diğer gruba, yine bu ilkelere göre hazırlanan, her alt bölümde sorularla desteklenen ders kitabı uygulanırken, kontrol grubu geleneksel ders kitabını izlemiş̧tir. Geleneksel ders kitabı, Mili Eğitim Bakanlığı Tarafından derslerde okutulmasına karar verilen Türkiye'de yaygın olarak kullanılan ders kitabıdır. 


\section{Sınırlılıklar}

- Araştırma, psikoloji ders kitabında, metinden öğrenme ilkelerini uygulamak için seçilen güdülenme ve algılama bölümlerinin öğrencilere kazandırmak istediği hedef davranışları kapsayan, erişi testleri sonucunda elde edilen veriler ve bu deneysel çalışma için ayrılan bir dönemlik süre ile,

- Çalışmada, "Metinden Öğrenme" verilen tanımıyla,

- Çalışma, lise psikoloji dersi alan öğrenciler ve dersin verildiği dönem ile sınırlandırılmıştır.

Çalışmada, okuduğunu anlama, ön test puanları değişkenlerine göre denkleştirilmiş, sorusuz, sorulu ve geleneksel ders kitabını takip eden üç grup oluşturulmuştur. Öğrenciler random yolla gruplara atanmışır. Bu değişkenler bakımından gruplar arasında farklılığı görme amacıyla tek yönlü varyans analizi uygulanmış ve farklıık bulunmamışıı. Yaş, cinsiyet, alınan dersler bakımından aralarında fark bulunmayan bu üç gruptaki öğrencilerin okuduklarını anlama düzeylerinin belirlenmesi amacıyla sözel yetenek testi uygulanmıştır. Kitapta seçilen iki bölüm için ayrı yapılan uygulamalar Tablo 1 ve Tablo 2 halinde aşağıda sunulmuştur.

Tablo 1.

Deney Deseni Güdülenme.

\begin{tabular}{lccccc}
\hline Gruplar & Test & Denel İşlem & Test & Zaman 6 Hafta & Test \\
\hline G1 & T1 & Sorusuz & T2 & Işslem Yok & T3 \\
G2 & T2 & Sorulu & T2 & & T3 \\
G3 & T3 & Geleneksel Ders Kitabı & T2 & & T3 \\
\hline
\end{tabular}

G1, G2 deney gruplarını, G3 ise kontrol gruplarını göstermektedir. Her üç gruba da denel işlemden önce ön test uygulanmıştır. Kullanılan test desende t ile gösterilmiştir.

Tablo 2.

Deney Deseni Algılama.

\begin{tabular}{lccccc}
\hline Gruplar & Test & Denel İşlem & Test & Zaman 6 Hafta & Test \\
\hline G1 & T1 & Sorusuz & T2 & İşlem Yok & T3 \\
G2 & T2 & Sorulu & T2 & & T3 \\
G3 & T3 & Geleneksel Ders Kitabı & T2 & & T3 \\
\hline
\end{tabular}

Analizlerde her üç grubun test puanları ve bilişsel alanın bilgi, kavrama, uygulama düzeyi erişileri ile toplam erişi puanlarının ortalamaları arasındaki farka bakılmışır. Ayrıca kalıcı izli davranış değişikliği bakımından gruplar arasındaki farkı görebilmek için, bilişsel alanın yukarıda açıklanan düzeyleri ile toplam erişi puanlarının ortalamaları arasındaki farka da bakıımışıı.

\section{Veri Toplama Aracı}

Araştırmada, işlem materyalleri olarak kullanılacak psikoloji ders kitabı güdülenme ve algılama bölümlerinin öğrencilere, bilgi, kavrama, uygulama düzeylerinde kazandırmak istediği hedef davranışlar doğrultusunda, araştırmacı tarafından hazırlanmış erişi testleri ile metinden öğrenme ilkelerini kapsayan metinleri değerlendirme ölçeği kullanılmışır. Hazırlanan metinler hakkında öğretim elemanları ve öğrencilerin görüşleri alınmıştır. Öğretim programında, bilgi düzeyinden uygulamaya kadar yazılan hedefler gözlenir öğrenci davranışlarına dönüştürülmüştür. Hedefler, davranışsal özellikleri kapsayacak şekilde ifade edilmiş sonra da bu davranışlara dayalı ölçme araçları geliştirilmiştir. Bilgi düzeyinde, öğrencilerin herhangi bir nesne ile ilgili özellikleri tanıma ya da yazma gibi davranışlar göstermelerine fırsat veren sorular bulunmakta ve bilgiler somuttan soyuta doğru gitmektedir. Kavrama düzeyinde öğrencinin önceki aşamada elde ettiği bilgileri, çevirmeleri ve yorumlamaları gerekmektedir. Ilişkiler arasında benzerlik ve farklılıkları görebilme bu düzeyde istenilen davranışlardır. Uygulama basamağında öğrencinin bilgi ve kavrama basamaklarındaki hedeflere dayalı olarak karşılaştı̆̆ı yeni bir sorunu çözmesi istenir. Bu düzeyde öğrencilerin güdülenme ve algılama konuları ile ilgili olarak ilke ve genellemeleri yeni durumlara uygulamalarını sağlayan davranışlar beklenmektedir.

Araştırmada ders kitabı olarak kullanılan geleneksel lise psikoloji ders kitabında başlangıçta ilke ve kavramlar bulunmamakta, konular teorik metinler tarzında sunulmuş, yeni bulgu ve uygulamalar bakımından eski olan bilgiler görsel düzenle desteklenmemiştir. Konu alt başlıkları sonunda az sayıda tartışma ve inceleme soruları bulunmaktadır. Konunun sonunda bölümde kazandırılmak istenilen davranışların kazanılma durumunu ölçen test soruları bulunmamaktadır. Hazırlanan ders kitabı ise bu nitelikleri taşımaktadır. 
Araştırmada psikoloji ders kitabının, güdülenme ve algılama konularına ilişkin eğitim durumlarının hedef davranışlara göre analizi yapıldığında, belirlenen hedef davranış sınıflamasının kapsam yönünden geçerli bir sınıflama olduğu görülmüştür. Daha sonra hedefler bilgi düzeyinden başlanarak, uygulama düzeyine kadar listeye işlenmiş, her iki bölüm için ayrı bir belirtke tablosu hazırlanmış bu tablolarda hedeflerin kapsadıkları davranışların ağırlıklarına göre, soru sayısı gösterilmiştir. Erişi testlerinin kapsam geçerliği konusunda daha önce hedef davranışların belirlenmesi aşamasında başvurulan uzmanlara tekrar danışımış, testlerin kapsadığı maddelerin psikoloji dersinde belirlenen konular çerçevesinde öğrencilere kazandırmak istediği davranışları yansıtarak, onları yeterli örnekleme konusunda birbirinden bağımsız olarak, beş psikoloji uzmanı görüşüne başvurulmuştur, \%75.00 oranında görüş birliğine varılan maddeler, bilgi, kavrama, uygulama düzeylerine göre sıralanarak 70 'er maddeden oluşan iki ayrı deneme formu hazırlanmış, deneme uygulamaları psikoloji dersini almakta olan bir gruba verilerek, uygulama sonuçlarına göre test ve test puanı analizleri yapılmış, belirtke tablosundan yararlanılarak, testin kapsam geçerliği zedelenmeden iki ayrı konu için 40'ar test maddesi seçilerek, erişi testleri oluşturulmuştur. Elde edilen testlerin KR20 güvenirlik katsayısı güdülenme ünitesinde $\mathrm{rx}=.83$, algılama konusunda $\mathrm{rx}=.85^{\prime}$ dir.

\section{Verilerin Analizi}

Sorusuz hazırlanan bölüm 1. gruba, sorularla desteklenen metin 2. gruba uygulanmış, kontrol grubuna ise, halen okutulmakta olan geleneksel psikoloji ders kitabı verilmiştir. Bölümler, 6 saatlik ders süresi içinde üç haftada tamamlanmıştır. Öğretim psikoloji öğretmeninin gözetiminde ancak öğretmenin katkısı olmadan gerçekleştirilmiştir. Öğrenme yaşantıları esnasında, öğrencilere, dönüt, düzeltme, pekiştireç, ipucu, sözel açıklama gibi değişkenler uygulanmamıştır. Kitaplardan doğrudan öğretim yapılmıştır. Öğrenciler, öğrenme yaşantıları esnasında kendi kendilerine çalışmalarında destek olacak şekilde kağıtlara çalışmalarını özetlemişler, kendi öğrenme yöntemlerini kullanmışlardır. Öğrencilerin nasıl çalıştıklarını gösteren kendi açıklamaları, bölümler tamamlandığında araştırmacı tarafından değerlendirilmiştir. Denel işlem süresince hazırlanan materyaller her ders başında öğrencilere dağıtılmış, ders sonlarında çalışma notları ile birlikte toplanmıştır. Araştırmacı, denel işlemin belirlenen koşullarda gerçekleşmesini kontrol altında tutmaya çalışmıştır. Ayrıca derslere düzenli bir şekilde katılarak öğrenciler için zaman zaman gözlem formu doldurmuştur. Deney ve kontrol grubundaki öğrenciler, çalışmalarının sonunda, kullandıkları yazıı materyallere, kendilerine uygulanan ders kitapları hakkında kısa bilgiler de sunmuşlardır. Öğrencilerin bölüm sonlarında yer alan izleme testine ilişkin cevapları (Güdülenme; 25, Algılama; 20 soru) değerlendirilmiştir.

Bu çalışmada, deney ve kontrol grubundaki öğrencilerin ön ve son test puanları ve bu puanlardan elde edilen bilgi, kavrama, uygulama erişileri ve toplam erişileri, öğrencilerin kalııı izli davranış değişikliği(hatırlama) bakımından erişi puanları elde edilmiştir. Hazırlanan testler, ön test, son test ve hatırlama testi ölçülerini elde etmek üzere deney ve kontrol gruplarını oluşturan öğrencilere üç kez uygulanmışır. Test uygulamalarında araştırmacının yanında iki uygulayıcı daha görev almıştır. Uygulama için verilen 40 dakikalık sürenin yeterli olduğu gözlenmiştir. Araştırmada, metinden öğrenme kitabını okuyan deney ve geleneksel kitabı okuyan kontrol grupları, derslerine, kitaplarını okumadan gelmişlerdir. Kontrol edilemeyen değişkenler, grupları eşit şekilde etkilemiştir. Öğrencilerin uygulama günlerinde okula düzenli gelmeleri sağlanarak, gün içinde test verme işlemi tamamlanmıştır. 1. konuda, bilişsel alanın bilgi, kavrama, uygulama ve toplam düzeydeki erişi ortalamaları arasındaki farka bakabilmek için ön test puanları, son-ön test ortalamaları arası farka ve kalıclık için uygulanan 3. test ile son test arasındaki erişi ortalamaları arasındaki farka bakılmışırı. Aynı uygulama algılama konusu için de yapılmışıır.

İstatistik analizlerde anlamlılık düzeyi $\mathrm{p}<.01$ olarak alınmıştır. Gruplar birbirinden bağımsız olduğu için her üç grupta da ders kitaplarının bilişsel alanın üç düzeyi ve toplam erişi üzerindeki etkisinin çözümlenmesi için tek yönlü varyans analizi yapılmıştır. Bu işlem sonucunda F değerleri anlamlı bulunmuştur. Her iki konuda belirtilen düzeylerde, son-ön test erişi ortalamaları ile kalıcılık bakımından uygulanan 3. test ile son test erişi ortalamaları arasındaki fark varyans analizi ile test edildiğinde gruplar arasında .01 manidarlık düzeyinde anlamlıık çıkı̆ı̆ından, independent $t$ testi kullanıımışır.

\section{Bulgular}

Bu bölümde örneklem ve varsayımlar ile ilgili toplanan veriler uygun istatistiksel teknikler kullanılarak analiz edilmiş ve tablolar halinde sunulmuştur. Örneklem ile ilgili bulgularda öğrencilerin okuduğunu anlama ve ön 
test puanları ile ilgili tek yönlü varyans analizi sonuçlarına bakılmış ve sonuçta her üç grubun okuduğunu anlama testi ortalamaları arasında anlamlı bir fark bulunmamıştır. Bu bilgiler ışığında grupların bu değişken açısından denk oldukları söylenebilir. Yine aynı şekilde her üç grubun ön test puanları arasında da anlamlı bir fark bulunmamıştır. Hazırlanan metnin değerlendirilmesi ile ilgili bulgulara bakıldığında, ölçek çalışmasından elde edilen sonuçlar, öğretim elemanları ve öğrenciler için ayrı olmak üzere aşağıda sunulmuştur.

\section{Hazırlanan Metnin Değerlendirilmesi ile ilgili Bulgular}

Tablo 3.

Hazırlanan Metnin Değerlendirilmesine Iliş̧kin Sorulan Sorulara Öğretim Elemanları Tarafından Verilen Ortalama Puanlar.

\begin{tabular}{lcrr}
\hline & Ortalama Puanlar & & \\
\cline { 2 - 3 } & $\mathbf{N}$ & $\mathbf{X}$ & S.S. \\
\hline Şekil & 7 & 14.57 & .78 \\
Konunun işleniş ve niteliği & 7 & 33.14 & 2.11 \\
Öğrenciye uygunluk & 7 & 14.57 & .53 \\
Metnin düzeni & 7 & 58.14 & 2.26 \\
\hline
\end{tabular}

Tablo 3 incelediğinde, hazırlanan ders kitaplarının şeklini, konuların işleniş ve niteliğini, öğrenciye uygunluğunu ve metin düzeni bakımlarından öğretim elemanlarının yeterli buldukları söylenebilir.

Tablo 4.

Hazırlanan Metnin Değerlendirilmesine ilişkin Sorulan Sorulara Öğrenciler Tarafından Verilen Ortalama Puanlar.

\begin{tabular}{lcrr}
\hline & Ortalama Puanlar & & \\
\cline { 2 - 3 } & $\mathbf{N}$ & 14.10 & S.S. \\
\hline Şekil & 76 & 33.01 & .90 \\
Konunun işleniş ve niteliği & 76 & 14.26 & 1.57 \\
Öğrenciye uygunluk & 76 & .91 \\
Metnin düzeni & 76 & 59.27 & 1.53 \\
\hline
\end{tabular}

Bu sonuç ile ders kitaplarının, şekil, konunun işleniş ve niteliği, öğrenciye uygunluğu ve metin düzeni bakımından öğrenciler tarafından da yeterli bulundukları söylenebilir.

\section{Güdülenme Konusuna illişkin Bulgular}

\section{Gruplar ve Toplam Düzeydeki Erişi}

Tablo 5.

Grupların Güdülenme Ünitesi Toplam Düzeydeki Erişi Puanlarına Ait Varyans Analizi.

\begin{tabular}{lrrrr}
\hline Varyansın Kaynağı & Kareler Toplamı & Serbestlik Derecesi & Ortalama Kareler Toplamı & F \\
\hline Gruplar Arası & 874.32 & 2 & 437.16 & $70.62^{*}$ \\
Gruplar İçi & 686.12 & 111 & 6.18 & \\
Toplam & 1561.24 & & & \\
\hline
\end{tabular}

$\mathrm{p}<.01$

Yapılan varyans analizi sonuçlarına göre, Tablo 5'te görüldüğü gibi grupların toplam erişi puanları arasında .01 manidarlık düzeyinde anlamlı bir fark görülmektedir. Bu farkın hangi gruplar arasında olduğunu belirlemek için t testi yapılmıştır. Bu veriler Tablo 6'da gösterilmiştir.

Tablo 6.

Grupların Güdülenme Ünitesi Toplam Düzeydeki Erişi Puanları ve t Değerleri.

\begin{tabular}{lrrcrrr}
\hline Gruplar & N & $\mathbf{X}$ & Erişi X & Erişi S & Sorusuz t & Geleneksel t \\
\hline Sorulu & 38 & 23.44 & 1 ile $2=1.66$ & 1 ile $3=.57$ & 23.72 & $124^{*}$ \\
Sorusuz & 38 & 21.78 & 2 ile 3 $=5.70$ & 2 ile 3 $=.59$ & - & $81.43^{*}$ \\
Geleneksel & 38 & 15.00 & 1 ile 3 $=7.44$ & 1 ile 3 $=.54$ & - & - \\
\hline
\end{tabular}


Tablo 6'daki verilere göre .05 anlamlılık düzeyi ve '74' serbestlik derecesinde gruplar arasında toplam erişiler açısından anlamlı bir fark olduğu söylenebilir. Bu sonuçlara göre, metinden öğrenme ilkelerine göre sorulu, sorusuz şekilde hazırlanan ders kitaplarının geleneksel kitaba göre toplam düzeydeki erişiyi anlamlı şekilde etkilediğini söylemek mümkündür. Bu farkın en fazla sorulu ders kitabını alan grup lehine görülmesi, soruların toplam erişi puanlarını anlamlı olarak etkilediği sonucuna bağlanabilir.

\section{Gruplar ve Bilgi Düzeyindeki Erişi}

Tablo 7.

Grupların Güdülenme Ünitesi Bilgi Düzeyi Erişi Puanlarına ait Varyans Analizi.

\begin{tabular}{|c|c|c|c|c|}
\hline Varyansın Kaynağı & Kareler Toplamı & Serbestlik Derecesi & Ortalama Kareler Toplamı & $\mathbf{F}$ \\
\hline Gruplar Arası & 68.96 & 2 & 34.48 & $6.54^{*}$ \\
\hline Gruplar İçi & 584.97 & 111 & 5.27 & \\
\hline Toplam & 653.93 & & & \\
\hline
\end{tabular}

$\mathrm{p}<.01$

Yapılan varyans analizi sonuçlarına göre, Tablo 7'de görüldüğü gibi grupların bilgi düzeyi erişi puanları arasında .01 manidarlık düzeyinde anlamlı bir fark görülmektedir. Bu farkın hangi gruplar arasında olduğunu belirlemek için t testi yapılmıştır. Bu veriler Tablo 8'de gösterilmiştir.

Tablo 8.

Grupların Güdülenme Ünitesi Bilgi Düzeyi Erişi Puanları ve t Değerleri.

\begin{tabular}{lrrcrrr}
\hline Gruplar & N & X & Erişi X & Erişi S & Sorusuz t & Geleneksel t \\
\hline Sorulu & 38 & 10.18 & 1 ile $2=.58$ & .39 & $14.50^{*}$ & $41.60^{*}$ \\
Sorusuz & 38 & 9.60 & 2 ile $3=1.5$ & .44 & - & $30.00^{*}$ \\
Geleneksel & 38 & 2.10 & 1 ile 3 $=2.08$ & .45 & - & - \\
\hline
\end{tabular}

$* p<.05$

Tablo 8'deki verilere göre .05 anlamlılık düzeyi ve '74' serbestlik derecesinde gruplar arasında bilgi düzeyi erişişi bakımından anlamlı bir fark olduğu söylenebilir. Bu sonuçlara göre, metinden öğrenme ilkelerine göre sorulu, sorusuz şekilde hazırlanan ders kitaplarının geleneksel kitaba göre bilgi düzeyindeki erişiyi anlamlı şekilde etkilediğini söylemek mümkündür. Bu farkın en fazla sorulu ders kitabını alan grup lehine görülmesi, soruların bilgi düzeyi erişi puanlarını anlamlı olarak etkilediği sonucuna bağlanabilir.

\section{Gruplar ve Kavrama Düzeyindeki Erişi}

Tablo 9.

Grupların Güdülenme Ünitesi Kavrama Düzeyi Erişi Puanlarına Ait Varyans Analizi.

\begin{tabular}{lrrrr}
\hline Varyansın Kaynağı & Kareler Toplamı & Serbestlik Derecesi & Ortalama Kareler Toplamı & F \\
\hline Gruplar Arası & 46.96 & 2 & 23.48 & $7.41^{*}$ \\
Gruplar İçi & 350.97 & 111 & 3.16 & \\
Toplam & 397.93 & & & \\
\hline
\end{tabular}

$p<.01$

Yapılan varyans analizi sonuçlarına göre, bulunan $\mathrm{F}$ değeri .01 düzeyinde gruplar arasında kavrama düzeyi erişişi bakımından anlamlı bir farkın olduğunu göstermektedir. Bu farkın hangi gruplar arasında olduğunu belirlemek için t testine başvurulmuştur. Bu veriler Tablo 10'da gösterilmiştir.

Tablo 10.

Grupların Güdülenme Ünitesi Kavrama Düzeyi Erişi Puanları ve t Değerleri.

\begin{tabular}{lrrcrrr}
\hline Gruplar & $\mathbf{N}$ & $\mathbf{X}$ & Erişi X & Erişi S & Sorusuz t & Geleneksel t \\
\hline Sorulu & 38 & 5.07 & 1 ile $2=.35$ & .37 & $8.75^{*}$ & $41.25^{*}$ \\
Sorusuz & 38 & 5.42 & 2 ile 3 $=2.00$ & .34 & - & $50.00^{*}$ \\
Geleneksel & 38 & 3.42 & 1 ile 3 $=1.65$ & .31 & - & - \\
\hline
\end{tabular}

$* p<.05$ 
Tablo 10'daki verilere göre .05 anlamlılık düzeyi ve '74' serbestlik derecesinde gruplar arasında kavrama düzeyi erişişi bakımından anlamlı bir fark olduğu söylenebilir. Bu sonuçlara göre, metinden öğrenme ilkelerine göre sorulu, sorusuz şekilde hazırlanan ders kitaplarının geleneksel kitaba göre kavrama düzeyindeki erişiyi anlamlı şekilde etkilediğini söylemek mümkündür. Bu farkın en fazla sorulu ders kitabını alan grup lehine görülmesi, soruların bilgi düzeyi erişi puanlarını anlamlı olarak etkilediği sonucuna bağlanabilir.

\section{Gruplar ve Uygulama Düzeyindeki Erişi}

Tablo 11.

Grupların Güdülenme Ünitesi Uygulama Düzeyi Erişi Puanlarına Ait Varyans Analizi.

\begin{tabular}{lrrrr}
\hline Varyansın Kaynağı & Kareler Toplamı & Serbestlik Derecesi & Ortalama Kareler Toplamı & F \\
\hline Gruplar Arası & 202.18 & 2 & 101.09 & $18.96^{*}$ \\
Gruplar İçi & 592.31 & 111 & 5.33 & \\
Toplam & 794.49 & & & \\
\hline
\end{tabular}

$p<.01$

Yapılan varyans analizi sonuçlarına göre, bulunan F değeri .01 düzeyinde gruplar arasında uygulama düzeyi erişişi bakımından anlamlı bir farkın olduğunu göstermektedir. Bu farkın hangi gruplar arasında olduğunu belirlemek için $t$ testine başvurulmuştur. Bu veriler Tablo 12' de gösterilmiştir.

Tablo 12.

Grupların Güdülenme Ünitesi Uygulama Düzeyi Erişi Puanları ve t Değerleri.

\begin{tabular}{lrrcrrr}
\hline Gruplar & $\mathbf{N}$ & $\mathbf{X}$ & Erişi X & Erişi S & Sorusuz t & Geleneksel t \\
\hline Sorulu & 38 & 8.23 & 1 ile $2=1.52$ & .55 & $25.33^{*}$ & $62.16^{*}$ \\
Sorusuz & 38 & 6.71 & 2 ile 3 $=2.21$ & .50 & - & $36.83^{*}$ \\
Geleneksel & 38 & 4.50 & 1 ile 3 $=3.73$ & .52 & - & - \\
\hline
\end{tabular}

$* p<.05$

Tablo 12'deki verilere göre .05 anlamlılık düzeyi ve '74' serbestlik derecesinde gruplar arasında uygulama düzeyi erişişi bakımından anlamlı bir fark olduğu söylenebilir. Bu sonuçlara göre, metinden öğrenme ilkelerine göre sorulu, sorusuz şekilde hazırlanan ders kitaplarının geleneksel kitaba göre uygulama düzeyindeki erişiyi anlamlı şekilde etkilediğini söylemek mümkündür. Bu farkın en fazla sorulu ders kitabını alan grup lehine görülmesi, soruların bilgi düzeyi erişi puanlarını anlamlı olarak etkilediği sonucuna bağlanabilir.

\section{Gruplar ve Hatırlama (Kalıcı İzli Davranış Değişikliği)}

Tablo 13.

Grupların Güdülenme Ünitesi Toplam Düzeyde Kalıcılık Puanlarına Ait Varyans Analizi.

\begin{tabular}{lrrrr}
\hline Varyansın Kaynağı & Kareler Toplamı & Serbestlik Derecesi & Ortalama Kareler Toplamı & F \\
\hline Gruplar Arası & 1370.01 & 2 & 685.00 & $96.75^{*}$ \\
Gruplar İçi & 785.92 & 111 & 7.08 \\
Toplam & 2155.93 & & & \\
\hline $\mathrm{p}<.01$ & & & &
\end{tabular}

Yapılan varyans analizi sonuçlarına göre, bulunan F değeri .01 düzeyinde grupların toplam düzeydeki kalıcılık puanları arasında anlamlı bir farkın olduğu görülmektedir. Bu farkın hangi gruplar arasında olduğunu belirlemek için " $t$ "testine başvurulmuştur. Bu veriler Tablo 14'te gösterilmiştir.

Tablo 14.

Grupların Güdülenme Ünitesi Toplam Düzeyde Kalıcılık Puanları ve t Değerleri.

\begin{tabular}{lrrcrrr}
\hline Gruplar & $\mathbf{N}$ & $\mathbf{X}$ & Erişi X & Erişi S & Sorusuz t & Geleneksel t \\
\hline Sorulu & 38 & 22.86 & 1 ile $2=2.13$ & .62 & $30.43^{*}$ & $136.33^{*}$ \\
Sorusuz & 38 & 20.73 & 2 ile $3=6.05$ & .65 & - & $86.43^{*}$ \\
Geleneksel & 38 & 14.68 & 1 ile $3=8.18$ & .54 & - & - \\
\hline
\end{tabular}

$* p<.05$ 


\section{Algılama Konusuna iliş̧kin Bulgular}

\section{Gruplar ve Toplam Düzeydeki Erişi}

Tablo 15.

Grupların Algılama Ünitesi Toplam Düzeydeki Erişi Puanlarına Ait Varyans Analizi.

\begin{tabular}{lrrrr}
\hline Varyansın Kaynağı & Kareler Toplamı & Serbestlik Derecesi & Ortalama Kareler Toplamı & F \\
\hline Gruplar Arası & 683.38 & 2 & 341.69 & $35.63^{*}$ \\
Gruplar İçi & 1062.05 & 111 & 9.57 & \\
Toplam & 1745.43 & & & \\
\hline
\end{tabular}

$p<.01$

Bulunan F değeri .01 anlamlılık düzeyinde toplam erişiler arasında anlamlı bir farkın olduğunu göstermektedir. Bu farkın hangi gruplar arasında olduğunu belirlemek için t testine başvurulmuştur. Bu veriler Tablo 16 'da gösterilmiştir.

Tablo 16.

Grupların Algılama Ünitesi Toplam Düzeydeki Erişi Puanları ve t Değerleri.

\begin{tabular}{lrrrrrr}
\hline Gruplar & $\mathbf{N}$ & $\mathbf{X}$ & Erişi X & Erişi S & Sorusuz t & Geleneksel t \\
\hline Sorulu & 38 & 10.76 & 1 ile $2=2.53$ & .69 & $31.25^{*}$ & $74.75^{*}$ \\
Sorusuz & 38 & 8.23 & 2 ile $3=3.45$ & .73 & - & $41.12^{*}$ \\
Geleneksel & 38 & 4.78 & 1 ile $3=5.98$ & .70 & - & - \\
\hline
\end{tabular}

$* p<.05$

Tablo 16 'daki verilere göre .05 anlamlılık düzeyi ve '74' serbestlik derecesinde gruplar arasında toplam düzeydeki erişiyi anlamlı şekilde etkilediğini söylemek mümkündür. Bu sonuçlara göre, metinden öğrenme ilkelerine göre sorulu, sorusuz şekilde hazırlanan ders kitaplarının geleneksel kitaba göre toplam düzeydeki erişiyi anlamlı şekilde etkilediğini söylemek mümkündür. Bu farkın en fazla sorulu ders kitabını alan grup lehine görülmesi, soruların toplam erişi puanlarını anlamlı olarak etkilediği sonucuna bağlanabilir.

\section{Gruplar ve Bilgi Düzeyindeki Erişi}

Tablo 17.

Grupların Algılama Ünitesi Bilgi Düzeyi Erişi Puanlarına Ait Varyans Analizi.

\begin{tabular}{lrrrr}
\hline Varyansın Kaynağı & Kareler Toplamı & Serbestlik Derecesi & Ortalama Kareler Toplamı & F \\
\hline Gruplar Arası & 140.13 & 2 & 70.07 & $22.24 *$ \\
Gruplar İçi & 349.81 & 111 & 3.15 & \\
Toplam & 489.93 & & & \\
\hline
\end{tabular}

$\mathrm{p}<.01$

Yapılan varyans analizi sonuçlarına göre, bulunan F değerleri .01 düzeyinde gruplar arasında bilgi düzeyi erişişi bakımından anlamlı bir fark olduğunu göstermektedir. Bu farkın hangi gruplar arasında olduğunu belirlemek için t testi yapılmıştır. Bu veriler Tablo 18' de gösterilmiştir.

Tablo 18.

Grupların Algılama Ünitesi Bilgi Düzeyi Erişi Puanları ve t Değerleri.

\begin{tabular}{lrrcrrr}
\hline Gruplar & N & X & Erişi X & Erişi S & Sorusuz t & Geleneksel t \\
\hline Sorulu & 38 & 3.97 & 1 ile $2=5.39$ & .40 & $107.80^{*}$ & $41.60^{*}$ \\
Sorusuz & 38 & 1.42 & 2 ile $3=.47$ & .42 & - & $9.40^{*}$ \\
Geleneksel & 38 & 1.89 & 1 ile 3 $=2.08$ & .47 & - & - \\
\hline
\end{tabular}

$* p<.05$

Tablo 18' deki verilere göre .05 anlamlılık düzeyi ve '74' serbestlik derecesinde gruplar arasında bilgi düzeyi erişişi bakımından anlamlı bir fark olduğu söylenebilir. Bu sonuçlara göre, metinden öğrenme ilkelerine göre sorulu, sorusuz şekilde hazırlanan ders kitaplarının geleneksel kitaba göre bilgi düzeyindeki erişiyi anlamlı şekilde etkilediğini söylemek mümkündür. Bu farkın en fazla sorulu ders kitabını alan grup lehine görülmesi, soruların bilgi düzeyi erişi puanlarını anlamlı olarak etkilediği sonucuna bağlanabilir. 


\section{Gruplar ve Kavrama Düzeyindeki Erişi}

\section{Tablo 19.}

Grupların Algılama Ünitesi Kavrama Düzeyi Erişi Puanlarına Ait Varyans Analizi.

\begin{tabular}{lrrrr}
\hline Varyansın Kaynağı & Kareler Toplamı & Serbestlik Derecesi & Ortalama Kareler Toplamı & F \\
\hline Gruplar Arası & 130.59 & 2 & 65.30 & $12.85^{*}$ \\
Gruplar İçi & 564.42 & 111 & 5.08 & \\
Toplam & 695.01 & & & \\
\hline
\end{tabular}

$\mathrm{p}<.01$

Yapılan varyans analizi sonuçlarına göre, bulunan $\mathrm{F}$ değeri .01 düzeyinde gruplar arasında kavrama düzeyi erişişi bakımından anlamlı bir farkın olduğunu göstermektedir. Bu farkın hangi gruplar arasında olduğunu belirlemek için t testine başvurulmuştur. Bu veriler Tablo 20'de gösterilmiştir.

Tablo 20.

Grupların Algılama Ünitesi Kavrama Düzeyi Erişi Puanları ve t Değerleri.

\begin{tabular}{lrrcrrr}
\hline Gruplar & $\mathbf{N}$ & $\mathbf{X}$ & Erişi X & Erişi S & Sorusuz t & Geleneksel t \\
\hline Sorulu & 38 & 3.47 & 1 ile $2=.21$ & .49 & $3.50^{*}$ & $47.40^{*}$ \\
Sorusuz & 38 & 3.26 & 2 ile $3=2.16$ & .58 & - & $30.85^{*}$ \\
Geleneksel & 38 & 1.10 & 1 ile 3 $=2.37$ & .46 & - & - \\
\hline
\end{tabular}

$* \mathrm{p}<.05$

Tablo 20'deki verilere göre .05 anlamlılık düzeyi ve '74' serbestlik derecesinde gruplar arasında kavrama düzeyi erişişi bakımından anlamlı bir fark olduğu söylenebilir. Bu sonuçlara göre, metinden öğrenme ilkelerine göre sorulu, sorusuz şekilde hazırlanan ders kitaplarının geleneksel kitaba göre kavrama düzeyindeki erişiyi anlamlı şekilde etkilediğini söylemek mümkündür. Bu farkın en fazla sorulu ders kitabını alan grup lehine görülmesi, soruların bilgi düzeyi erişi puanlarını anlamlı olarak etkilediği sonucuna bağlanabilir

\section{Gruplar ve Uygulama Düzeyindeki Erişi}

Tablo 21.

Grupların Algılama Ünitesi Uygulama Düzeyi Erişi Puanlarına Ait Varyans Analizi.

\begin{tabular}{|c|c|c|c|c|}
\hline Varyansın Kaynağı & Kareler Toplamı & Serbestlik Derecesi & Ortalama Kareler Toplamı & $\mathbf{F}$ \\
\hline Gruplar Arası & 36.70 & 2 & 18.35 & $4.37^{*}$ \\
\hline Gruplar İçi & 465.86 & 111 & 4.20 & \\
\hline Toplam & 502.56 & & & \\
\hline
\end{tabular}

$\mathrm{p}<.01$

Yapılan varyans analizi sonuçlarına göre, bulunan F değeri .01 düzeyinde gruplar arasında uygulama düzeyi erişişi bakımından anlamlı bir farkın olduğunu göstermektedir. Bu farkın hangi gruplar arasında olduğunu belirlemek için $t$ testine başvurulmuştur. Bu veriler Tablo 22' de gösterilmiştir.

Tablo 22.

Grupların Algılama Ünitesi Uygulama Düzeyi Erişi Puanları ve t Değerleri.

\begin{tabular}{lrrcrrr}
\hline Gruplar & $\mathbf{N}$ & $\mathbf{X}$ & Erişi X & Erişi S & Sorusuz t & Geleneksel t \\
\hline Sorulu & 38 & 3.34 & 1 ile $2=.48$ & .49 & $8.00^{*}$ & $27.40^{*}$ \\
Sorusuz & 38 & 2.86 & 2 ile 3 $=.89$ & .54 & - & $14.63^{*}$ \\
Geleneksel & 38 & 1.97 & 1 ile 3 1.37 & .42 & - & - \\
\hline
\end{tabular}

$* p<.05$

Tablo 22'deki verilere göre .05 anlamlılık düzeyi ve '74' serbestlik derecesinde gruplar arasında uygulama düzeyi erişişi bakımından anlamlı bir fark olduğu söylenebilir. Bu sonuçlara göre, metinden öğrenme ilkelerine göre sorulu, sorusuz şekilde hazırlanan ders kitaplarının geleneksel kitaba göre kavrama düzeyindeki erişiyi anlamlı şekilde etkilediğini söylemek mümkündür. Bu farkın en fazla sorulu ders kitabını alan grup lehine görülmesi, soruların bilgi düzeyi erişi puanlarını anlamlı olarak etkilediği sonucuna bağlanabilir. 


\section{Gruplar ve Hatırlama (Kalıcı İzli Davranış Değişikliği)}

\section{Tablo 23.}

Grupların Algılama Ünitesi Toplam Düzeyde Kalıcılık Puanlarına Ait Varyans Analizi.

\begin{tabular}{lrrrr}
\hline Varyansın Kaynağı & Kareler Toplamı & Serbestlik Derecesi & Ortalama Kareler Toplamı & F \\
\hline Gruplar Arası & 1145.07 & 2 & 572.54 & $57.20^{*}$ \\
Gruplar İçi & 1111.18 & 111 & 10.01 & \\
Toplam & 2256.25 & & & \\
\hline
\end{tabular}

$p<.01$

Yapılan varyans analizi sonuçlarına göre, grupların toplam düzeydeki kalıcılık puanları arasında .01 manidarlık düzeyinde anlamlı bir farkın olduğu görülmektedir. Bu farkın hangi gruplar arasında olduğunu belirlemek için $t$ testine başvurulmuştur. Bu veriler Tablo 24 'te gösterilmiştir.

Tablo 24.

Grupların Algılama Ünitesi Toplam Düzeyde Kalıcılık Puanları ve t Değerleri.

\begin{tabular}{lrrcrrr}
\hline Gruplar & $\mathbf{N}$ & $\mathbf{X}$ & Erişi X & Erişi S & Sorusuz t & Geleneksel t \\
\hline Sorulu & 38 & 26.23 & 1 ile $2=3.87$ & .69 & $48.37^{*}$ & $86.22^{*}$ \\
Sorusuz & 38 & 22.36 & 2 ile 3 $=3.89$ & .74 & - & $43.22^{*}$ \\
Geleneksel & 38 & 18.47 & 1 ile 3 $=7.76$ & .74 & - & - \\
\hline
\end{tabular}

$* p<.05$

Tablo 24'deki verilere göre .05 anlamlılık düzeyi ve '74' serbestlik derecesinde gruplar arasında toplam düzeydeki erişiyi anlamlı şekilde etkilediğini söylemek mümkündür. Bu sonuçlara göre, metinden öğrenme ilkelerine göre sorulu, sorusuz şekilde hazırlanan ders kitaplarının geleneksel kitaba göre toplam düzeydeki erişiyi anlamlı şekilde etkilediğini söylemek mümkündür. Bu farkın en fazla sorulu ders kitabını alan grup lehine görülmesi, soruların toplam erişi puanlarını anlamlı olarak etkilediği sonucuna bağlanabilir.

Bulgular, araştırmanın başlangıcında toplam erişileri, bilgi, kavrama, uygulama ve kalıcı izli davranış değişikliği bakımlarından gruplar arasında metinden öğrenme ilkelerine göre hazırlanan ders kitaplarının daha etkili olduğu varsayımlarını desteklemiştir.

Lise psikoloji dersinde metinden öğrenme ilkelerine göre hazırlanan ders kitabının kullanıldığı grup ile, bu ilkelere göre yazılan ancak sorularla desteklenmiş olan kitabın kullanıldığı grubun toplam erişileri ile geleneksel ders kitabının uygulandığı grubun;

- Toplam erişileri arasında,

- Bilgi düzeyleri erişisi arasında,

- Kavrama düzeyi erişisi arasında,

- Uygulama düzeyi erişisi arasında ve

- Kalıcı izli davranış değişikliği (hatırlama) bakımından aralarında anlamlı bir fark vardır.

Denencelerin elde edilen bulgular ile desteklenmesi, metinden öğrenme ilkelerine göre hazırlanan ve sorular ile desteklenen ders kitaplarının, geleneksel kitaplara göre, öğrenci başarısını arttıran özelliklerine bağlanabilir. Bu şekilde hazırlanan ders kitapları öğrencileri çalışmaya güdüleyerek, konu alt başlıklarında temel kavramlar, örnek deneyler, özetler, sorular, aralıklı tekrarlar yolu ile bilgilerin pekiştirilmesinde ve hatırlamanın güçlendirilmesinde etkili olmuştur denebilir. Konuların anlamlı bir şekilde düzenlenip, açıklandığı, öğrencinin ilgisini çeken bir tarzda sunulduğu, alt başlıkların öğrenilmesinin, bütünün öğrenilmesinde etkili olduğu ve konu sonlarında testler yolu ile öğrenmenin pekiştirildiği öğrenme yaşantıları esnasında kazanılan bilgiler daha kalıcı olabilmektedir.

\section{Tartışma, Sonuç ve Öneriler}

Metinden öğrenme ilkelerine göre hazırlanan sorusuz, bu ilkelere göre yazılan ancak sorularla desteklenmiş olan ders kitaplarının, geleneksel ders kitabına göre öğrenci erişisi üzerindeki etkilerini değerlendirmek amacıyla yapılan bu araştırmada;

1. Metinden öğrenme ilkelerine göre hazırlanan sorulu ve sorusuz ders kitaplarının, geleneksel ders kitabına göre toplam erişi üzerinde daha fazla etkisi olduğu görülmüştür. Bu etki en fazla sorulu ders kitabı kullanan grup lehine olmuştur. 
2. Metinden öğrenme ilkelerine göre hazırlanan sorulu ve sorusuz ders kitaplarının geleneksel ders kitabına göre bilişsel alanın bilgi düzeyinde daha etkili olduğu belirlenmiştir. Bu etki en fazla sorulu ders kitabını kullanan grup lehine bulunmuştur.

3. Metinden öğrenme ilkelerine göre hazırlanan sorulu ve sorusuz ders kitaplarının, geleneksel ders kitabına göre, öğrencilerin kavrama düzeyi erişileri üzerinde daha etkili olduğu görülmüştür. 1. ünitede (Güdülenme) gruplar arasında görülen anlamlı fark, sorusuz ders kitabını kullanan grup lehine bulunmuştur.

4. Metinden öğrenme ilkelerine göre hazırlanan sorulu ve sorusuz ders kitaplarının, geleneksel ders kitabına göre, öğrencilerin uygulama düzeyi erişileri üzerinde daha etkili olduğu görülmüştür. Bu etki, en fazla sorulu ders kitabını kullanan grup lehine bulunmuştur.

5. Metinden öğrenme ilkelerine göre hazırlanan sorulu ve sorusuz ders kitaplarının, geleneksel ders kitabına göre kalıcılık bakımından öğrencilerin toplam erişileri üzerinde daha etkili olduğu görülmüştür.

Gruplar arasında, metinden öğrenme ilkelerine göre hazırlanan sorusuz ve sorularla desteklenen gruplarda, geleneksel ders kitabını alan gruba göre, özellikle sorulu grup lehine çıkan anlamlı fark hem metinden öğrenme ilkelerine hem de zihinsel alanın bilgi, kavrama, uygulama düzeylerine uygun şekilde hazırlanan öğrenmeyi destekleyen sorulara bağlanabilir. Bloom, Englehart, Furst, Hill ve Krathwohl (1956) bilişsel, duyuşsal ve psikomotor olmak üzere üç öğrenme türünden söz etmiştir. Öğrenme düzeylerini temele alarak bu alanları alt başlıklara ayırmıştır. Çalışmada Bloom vd.'nin (1956) geleneksel taksonomisinde zihinsel alanla ilgili bilgi, kavrama, uygulama analiz, sentez değerlendirme düzeylerinden ilk üç basamağın çalışılmasının nedenleri, eğitimde istendik davranışların basitten karmaşığa aşamalı bir şekilde sıralanmaları ve bu düzeydeki öğrenmelerin, üst düzey bilişsel öğrenmeler için ön koşul olmaları ile açıklanabilir. Metinden öğrenme ilkelerinin bilgi, kavrama, uygulama düzeylerindeki etkisini araştıran bu çalışmanın sonuçları analiz, sentez ve değerlendirme düzeyleri için yeni ders kitaplarının hazırlığına katkı getirebilir. Metinden öğrenme ilkelerine göre hazırlanan ders kitaplarının, geleneksel ders kitabına göre kalııılık bakımından öğrencilerin toplam erişileri üzerinde daha etkili olması, gruplar arasında görülen anlamlı farkın, sorulu ders kitabını kullanan grup lehine bulunması ders kitaplarında, metinden öğrenme ilkelerinin, özellikle görsel düzenin ve öğrenilenlerin alışırmalar ile desteklenmesinin önemini vurgulamaktadır. Bodur (2016) kitaplarda yazı ve görüntünün birbirini tamamladığıı ve yazıların görsel öğelerle desteklenmesi ile konuların daha kolay anlaşıldığını vurgulamaktadır.

Dündar (1995); Ergin ve Gözütok (1996) araştırmalarında, öğretmenlerin ders kitaplarında öğrencinin dikkatini çeken, ilginç bilgiler veren, görsel öğelere yer verilmediğini, ders kitabının hazırlı̆̆ ve basımı aşamalarının konu uzmanları tarafından ele alınması gerektiğini vurgulamışlardır. Kabapınar (2001), Türk ve İngiliz Fen kitaplarını görsel öğeler açısından karşılaştırdığı araştırmasında, İngiliz ders kitaplarında bulunan görsel öğelerin, Türkiye'deki kitaplarda kullanılanlardan üç kat daha fazla olduğunu belirtmiştir. Şahin (2004) kitabın içerdiği metinlerin görsel malzemeyle çekici hale geldiğini belirtmiş, Coşkun (2003) çalışmasında, içeriğin resim, fotoğraf, grafik, tablo ve şekillerle desteklenmesinin önemini vurgulamıştır. Duman (2003) kitap içeriğinin, güncel, objektif, ezber yerine, bireyi düşündürmeye yönlendiren problemi çözmeyi, keşfetmeyi ve eleştirel düşünmeyi geliştirmesinin ve kitapların metinden öğrenme ilkelerine uygun hazırlanmasının önemini belirtmiştir.

Çerçi'de (2016) ders kitaplarında yer alan etkinlikleri amaç, içerik, öğretmen, öğrenci sorumluluğu ve sorular şeklinde temel unsurları ile kitapların eğitimdeki temel rolünü vurgulamıştır. Bu çalışmalarda da görüldüğü gibi, ders kitapları metinden öğrenme ilkelerine göre düzenlendiğinde, öğrenci başarısını arttırmaktadır. Ders kitapları içerik, anlatım, görsellik ve öğretim açısından çok iyi düzenlenmelidir. Metinden öğrenme ilkeleri, bu niteliklerin tamamlanmasında çok önemlidir.

Çalışmada, metinden öğrenme ilkelerine göre hazırlanan ders kitaplarııı, geleneksel ders kitabına göre toplam erişi üzerinde daha fazla etkide bulunduğu sonucu bulunduğundan, öğretmenler öğrenme yaşantıları esnasında öğrenci başarısı ve eğitimde verimin artması bakımından bu ilkeleri esas alan kitapları kullanmalıdırlar.

Metinden öğrenme ilkelerine göre hazırlanan sorusuz ve bu ilkelere göre hazırlanan sorulu ders kitaplarının, geleneksel ders kitabına göre bilişsel alanın bilgi, kavrama, uygulama düzeylerinde daha fazla etkisi belirlendiğinden, orta öğretim ders kitaplarında yer alan konuların ayrı ayrı bu düzeylerdeki hedefler çerçevesinde yeterlilikleri değerlendirilmelidir.

Metinden öğrenme ilkelerine göre hazırlanan ders kitaplarının geleneksel kitaplara göre öğrencilerin kavrama düzeyi erişileri üzerinde daha etkili olduğu sonucu bulunduğundan öğrencilere çalışmaları esnasında kullandıkları ders notları aracııı̆ı ile bilgi basamağında elde ettikleri davranışlara dayalı örneğin yorumlama, eşleştirme, örnekler verme gibi davranışlar yapmalarına fırsat verilmelidir. 
Metinden öğrenme ilkelerine göre hazırlanan sorusuz ve sorularla desteklenen ders kitaplarının, geleneksel ders kitabına göre, öğrencilerin uygulama düzeyi erişileri üzerinde daha etkili olduğu görüldüğünden, orta öğretimde psikoloji ve diğer derslerde kullanılan kitaplarda yer alan bölümlerin, bilişsel alanın uygulama düzeyi ile ilgili hedefleri, metinden öğrenme ilkelerine dayalı olarak gözden geçirilerek düzenlemeler yapılmalı, öğrenciye her ders için problem çözme örüntüsünü kullanacak fırsatlar verilmelidir.

Metinden öğrenme ilkelerine göre hazırlanan sorusuz ve sorularla desteklenen ders kitaplarının, geleneksel ders kitabına göre hatırlama bakımından öğrencilerin toplam erişileri üzerinde anlamlı etkisi bulunduğundan bu ilkelere göre, ders kitapları düzenlenirken, öğrenilenlerin kalıcılığını arttıran alıştırmalar özenle hazırlanmalıdır.

Ders kitapları, bilgi yükleyici, ezberciliğe dayanan geleneksel yöntem anlayışı yerine, program geliştirme çalışmalarında, değişen amaçların göz önünde tutulduğu, düzenlenmeler yapılarak yenilenmelidir.

Metinden öğrenme ilkelerini kapsayan ders kitapları ile ilgili yeni araştırmalar, daha geniş gruplar üzerinde farklı okul ve farklı sınıf düzeylerinde yapılabilir. Bu ilkeleri esas alan kitapların, kalıcı izli davranış değişikliği bakımından etkisini daha uzun süreler içinde araştıran yeni çalışmalar düzenlenmelidir. Ders kitaplarındaki etkinlikler bilişsel istem düzeyini arttırmalıdır.

Bilişsel alanın bilgi, kavrama, uygulama düzeyleri üzerinde etkisi olduğu belirlenen metinden öğrenme ilkelerinin, alanın analiz, sentez, değerlendirme gibi ileri düzeyleri üzerinde de etkili olup olmadığını belirleyecek çalışmalar planlanmalıdır. 


\section{References}

Alpan, B. G. (2004). Ders kitaplarındaki grafik tasarımının öğrenci başarısına ve derse ilişkin tutumlarına etkisi. Unpublished doctoral dissertation, Ankara Üniversitesi, Ankara.

Altunoğlu, B. D. \& Atav, E. (2005). Daha etkili bir biyoloji öğretme için öğretmen beklentileri. Hacettepe Eğitim Fakültesi Dergisi, 28, 19-28.

Arslan, S. \& Özpınar, ì. (2009). İlköğretim 6. sınıf matematik ders kitaplarını öğretmen görüşleri doğrultusunda değerlendirilmesi. Dicle Üniversitesi Ziya Gökalp Eğitim Fakültesi Dergisi, 12, 97-113.

Aslantaş, H. \& Demirci, B. (2016). Müzik ders kitaplarındaki görsellere ilişkin öğretmen görüşleri. Atatürk Üniversitesi Sosyal Bilimler Enstitüsü Dergisi, 20 (4), 1581-1599.

Balaman, F. (2016). The effect of digital storytelling technique on the attitudes of students toward teaching technologies. Pegem Eğitim ve Öğretim Dergisi, 6(2), 147-168.

Balaman, F. ve Tüysüz, C. (2011). Harmanlanmış öğrenme modelinin 7. sınıf öğrencilerinin fen ve teknoloji dersindeki başarılarına, tutumlarına ve motivasyonlarına etkisinin incelenmesi. Batı Anadolu Eğitim Bilimleri Dergisi, 2(4), 75-90.

Bloom, B., Englehart, M., Furst, E., Hill, W. \& Krathwohl, D. (1956). Taxonomy of educational objectives: The classification of educational goals. Handbook l: Cognitive domain. New York, Toronto: Longmans, Green.

Bodur, F. (2016). Uzaktan öğretim ders kitaplarında kullanılan görsel öğelerin öğrenmeye etkileri (Anadolu Üniversitesi örneği). Eğitim ve Öğretim Araştırmaları Dergisi, 5 (1), 70-80.

Bolat, Y. (2014). Öğrenci gözüyle sınıfın örtük programı. Adıyaman Üniversitesi Sosyal Bilimler Enstitüsü Dergisi, 7 (18), 510-536.

Çerçi, A. (2016). 6. sınıf Türkçe dersi öğrenci çalışma kitabının etkinliği oluşturan unsurlar bakımından değerlendirilmesi. Uluslararası Türkçe Edebiyat Kültür Eğitim Dergisi, 5 (4), 1984-1998.

Coşkun, M. (2003). Sosyal bilgiler ders kitaplarındaki coğrafya ünitelerinin içerik yönünden değerlendirilmesi. In: C. Şahin (Ed), Konu alanı ders kitabı inceleme kılavuzu sosyal bilgiler (pp. 299-315). Ankara: Gündüz Eğitim ve Yayınları.

Demirel, Ö. (1999). Planlamadan değerlendirmeye öğretme sanatı. Ankara: Pegem A Yayıncılık.

Duman, A. (2003). Sosyal bilgiler ders kitaplarında dil ve anlatım. In: C. Şahin (Ed), Konu alanı ders kitabı inceleme kılavuzu sosyal bilgiler (pp.124). Ankara: Gündüz Eğitim ve Yayınları.

Dursun, F. \& Eşgi, N. (2008). 4. ve 5. sınıf sosyal bilgiler öğretimi ders kitaplarının görsel tasarım ilkelerine göre değerlendirilmesi. Gazi Üniversitesi Endüstriyel Sanatlar Eğitim Fakültesi Dergisi, 22, 21-34.

Dündar, A. (1995). Ortaokul temel ders kitaplarının eğitsel ve grafiksel açıdan değerlendirilmesi. Unpublished master's thesis, Gazi Üniversitesi, Ankara.

Ergin, A. \& Gözütok, D. (1996). İlköğretim ders kitaplarının değerlendirilmesi (hayat örneği). In H. Coşkun, i. Kaya \& J. Kuplin (Ed.), Türkiye ve Almanya'da Illköğretim Ders Kitapları (pp. 77-85). Ankara: Bizim Büro Basımevi.

Eşgi, N. (2005). illköğretim 5. sınıf bilgisayar ders kitaplarının görsel tasarım ilkelerine göre değerlendirilmesi. Milli Eğitim Dergisi, 165. Retrieved from http://yayim.meb.gov.tr/dergiler/165/esgi.htm.

Güneş, F. (2002). Ders kitaplarının incelenmesi. Ankara: Ocak Yayınları.

ışı, C. (2008). İlköğretim ikinci kademesinde matematik öğretmenlerinin matematik ders kitabı kullanımını etkileyen etmenler. Kastamonu Eğitim Dergisi, 16 (1), 163-176.

Kabapınar, F. (2001). İşlevleri ve kavramsal anlamaya katkıları açılarından Türk ve İngiliz fen kitaplarındaki görsel öğeler. In Yeni Binyılın Başında Türkiye'de Fen Bilimleri Eğitimi Sempozyumu (pp. 131-138). İstanbul: Maltepe Üniversitesi.

Kabapınar, F. (2003). Oluşturmacı anlayışı yansıtması açısından Türk ve İngiliz fen bilgisi kitaplarındaki görsel öğeler. Hacettepe Eğitim Fakültesi Dergisi, 25, 119-126.

Kibarkaya, M. (1996). Ilköğretim ders kitaplarında tasarım sorunları ve uygulama çalışmaları. Unpublished master's thesis, Hacettepe Üniversitesi, Ankara. 
Özay, E. \& Hasenekoğlu, í. (2007). Lise-3 biyoloji ders kitaplarındaki görsel sunumla gözlemlenen bazı sorunlar. Türk Fen Eğitimi Dergisi, 4 (1), 80-91.

Şahin, H. (2004). Etkili bir sosyal bilgiler ders kitabinin nitelikleri. Kazım Karabekir Eğitim Fakültesi Dergisi, 9, 365-375.

Soong, B. C. \& Yager, R. E. (1993). The inclusion of STS material in the most frequently used secondary science textbook. U.S. Journal of Research in Science Teaching, 30 (4), 339-349.

Thompson, T. M. \& Wiggins, K. L. (1988). Multiveriate limits an continuity. An survey of calculus textbooks (Report No:143). Washington, DC: Resources in Education, Office of Educational Research and Improvement.

Tyree, R. B. (1994). Instructional materials for diverse learners. Features and considerations for textbook design. Remedial and Special Education, 15 (6), 363-377.

Ünal, S. \& Pideci, N. (2000, June). Lise kimya dersleri için öğretim materyalleri geliştirme çalışmaları. Paper presented at the 4th Ulusal Fen Bilimleri Eğitimi Sempozyumu, Niğde. Abstract retrieved from http://kongre.nigde.edu.tr/xufbmek/dosyalar/bildiri.pdf.

Ünsal, Y. \& Güneş, B. (2003). İlköğretim 6. sınıf fen bilgisi ders kitabının fizik konuları yönünden incelenmesi. Gazi Eğitim Fakültesi Dergisi, 23 (3), 115-130.

Yalın, H. I. (1996, October). Ders kitaplarının değerlendirilmesi. Paper presented at the 6th. Milli Eğitim Sempozyumu, Kütahya.

Yanpar, T. (2006). Öğretim teknolojileri ve materyal tasarımı (7th ed.). Ankara: Anı Yayıncılık.

Yeşilyurt, S. \& Gül, Ş. (2008). Ortaöğretimde daha etkili bir biyoloji öğretimi için öğretmen ve öğrenci beklentileri. Kastamonu Eğitim Dergisi, 16 (1), 145-162.

Yıldıran, N. B. (2007). Ilköğretim 8. sınıf bilgisayar ders kitaplarının görsel tasarım ilkelerine uygunluğunun değerlendirilmesi ve içerik analizinin yapılması. Unpublished master's thesis, Çukurova Üniversitesi, Adana. 
